\title{
A VISEGRÁDI KIRÁLYI PALOTA KÖZÉPKORI EMÉSZTŐJÉNEK LELETEI
}

\author{
Kocsis EDIT*
}

The study describes the household items and furnishings of the court through the pottery and glass finds recovered from the cesspit of the royal palace at Visegrád, alongside an examination of the assemblage's composition and its place of origin. A comparison of the mid-14th and late 15th century finds sheds light on the changes that took place during this period.

Keywords: Middle Ages, Visegrád, albarello, oil lamp, wine mixing vessel, storage vessel

A tanulmány a visegrádi királyi palota emésztöjében talált kerámia- és üveganyagon keresztül mutatja be az udvar használati és berendezési tárgyait, vizsgálja a leletanyag összetételét, származási helyét. A 14. század közepi és 15. század végi leleteket összevetve jellemzi az idóközben lezajlott változásokat.

Kulcsszavak: középkor, Visegrád, albarello, lámpás, borvegyítő edény, tárolóedény

\begin{abstract}
A lelóhely
Visegrádon 2006 nyarán - a Mátyás Király Múzeum jelenlegi fóbejárata mellett - a királyi palota északnyugati szárnyának déli végét tárták fel. ${ }^{1}$ Az ásatások során - többek között - a palota Mátyás-kori nagy konyhája, egy valószínúleg kamrának használt helyiség, egy emésztő és a Nagy Lajos-kori palota konyharészlete került napvilágra. Az emésztó eredetileg az attól délre fekvő Nagy Lajos-kori konyha számára készült. Mátyás uralkodása idején a konyhát az emésztó északi oldalára helyezték át, a hulladék elhelyezése azonban nem változott (1. kép). A Mátyáskori használatbavételt alapos tisztítás előzte meg,

A kézirat érkezett: 2016. március 1.

* Kocsis Edit. Magyar Nemzeti Múzeum - Mátyás Király Múzeum. 2025 Visegrád, Fő u. 23. n.kocsisedit@gmail.com

1 Sző́ke Mátyás és Buzás Gergely feltárása. A tanulmány rajzos tábláit Boldizsár Péternek és Molnár Évának köszönöm.
\end{abstract}

így a betöltés - a fenekén maradt kevés leletanyagot kivéve - a Mátyás-kori palotai élet, valamint az 1544-es pusztulásig tartó korszak hulladékait tartalmazta. Ez a leletegyüttes bőséges információt szolgáltatott a középkori királyi udvar főzési és étkezési szokásairól, a konyha és az ebédlőtermek használati tárgyairól, a palota egykori berendezéséről.

\section{Az emésztő}

A négyszögletes alaprajzú, kőből falazott emésztő $3 \mathrm{~m}$ mély volt. A palotaszárnnyal együtt utólag építették a palota nyugati zárófalához. Az emésztó alapozása fél méterrel mélyebb a körítőfal alapozásánál, északi fala takarta a körítófal egyik gerendafészkét. Az emésztőtől északra helyezkedett el az északnyugati palotaszárny Mátyás-kori konyhája, nyugatra pedig egy kis kamrát alakítottak ki. Innen egy rézsûsen falazott ledobónyílás vezetett az emésztóbe. Az emésztő déli falán is 


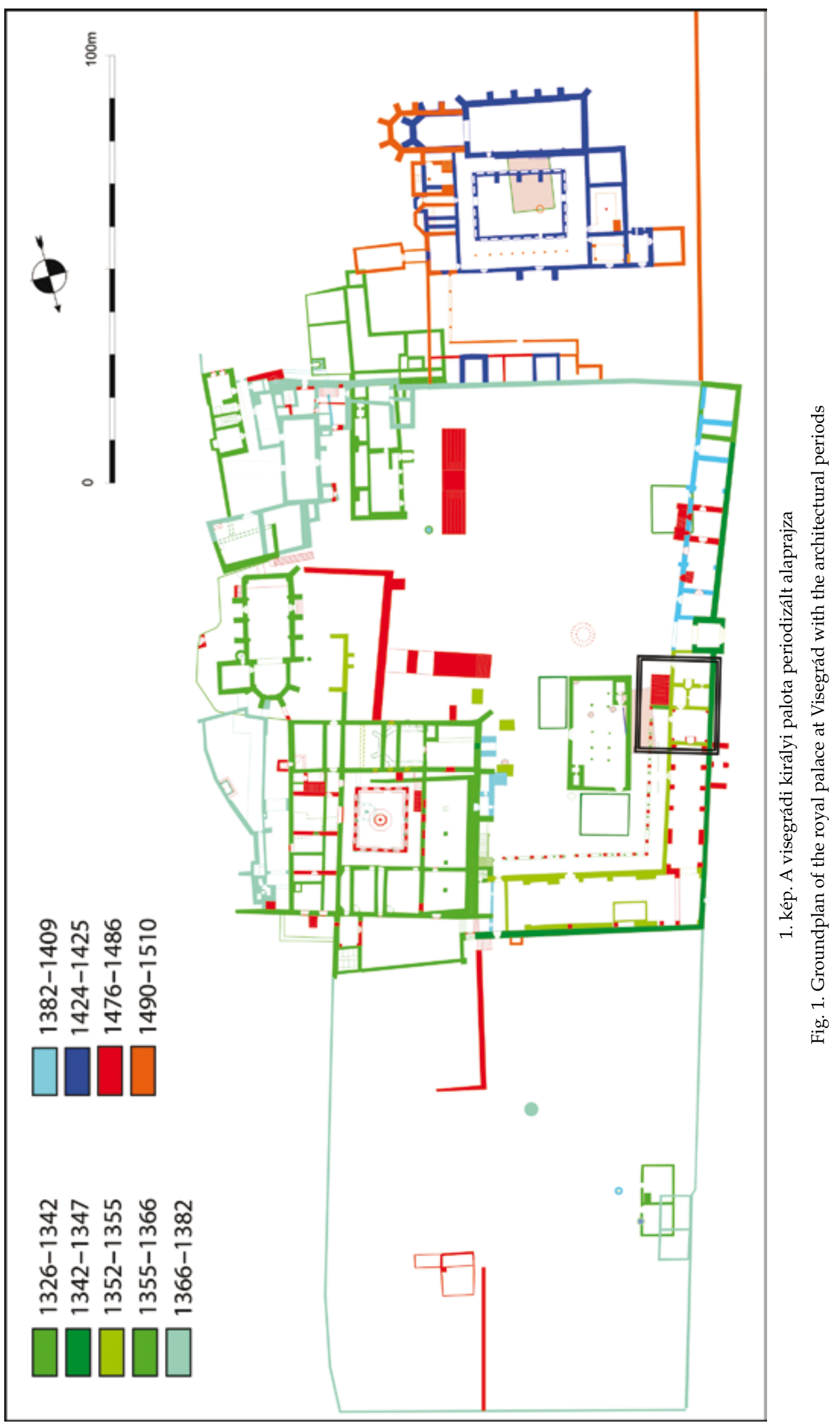




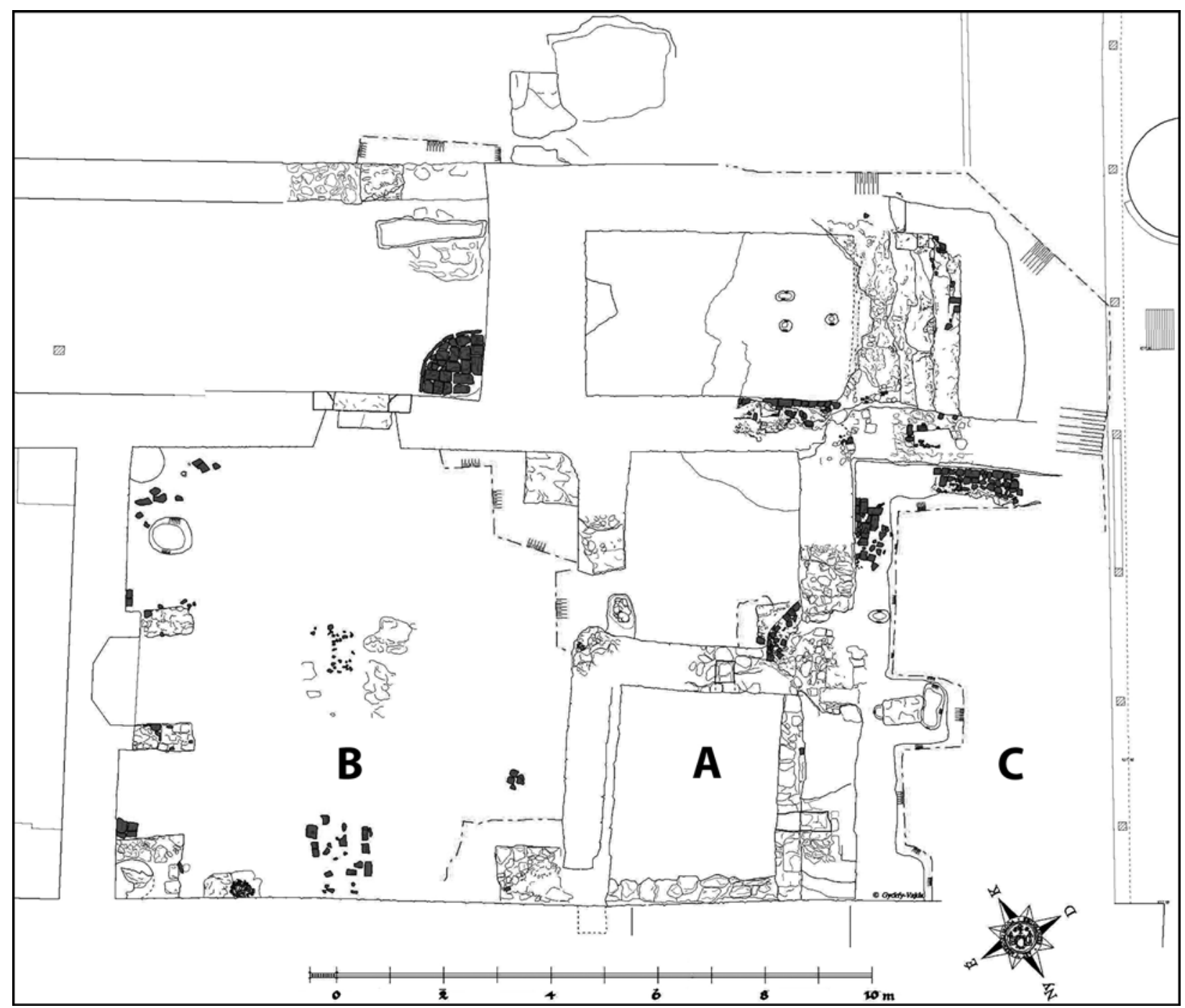

2. kép. A 2006-os ásatások helyszínrajza. A: emésztő; B: Mátyás kori konyha; C: Nagy Lajos kori konyha

Fig. 2. Plan of the 2006 excavation season. A: cesspit; B: kitchen of the 1470s; C: kitchen of the 1350s

nyílt egy kőkeretes ajtóval elzárható ledobónyílás, amely a palotaszárny Anjou-kori konyhájából nyílt. Ebből a konyhából a mosogatóvíz elvezetésére szolgáló csatorna is futott az emésztó felé. Később a déli oldalon lévő konyhát már nem használták, a szemétledobó nyílást elfalazták (2-3. kép).

\section{A betöltés}

Az emésztőt szinte teljesen megtöltötte a konyhai hulladék: állatcsont, tojáshéj, halpikkely, valamint fóző-, tároló- és asztali cserép- és üvegedények darabjai. A palota berendezési tárgyainak maradványai, elbontott Zsigmond-kori kályhák töredékei mellett több, különleges lelet is akadt, például egy Szíriában készült albarello, ${ }^{2}$ valamint Mátyás-kori összetört lámpások és csillárok jól rekonstruálható töredékei, ${ }^{3}$ továbbá két nagy, mázas borosedény darabjai. A szemét nagyrészt a déli szemétledobó aknán érkezett: ezen a helyen a hulladékkúp egyértelmúen kivehető volt.

A betöltésből kevés fémlelet - néhány vasszög töredéke, valamint egy vékony bronz övcsat került napvilágra. ${ }^{4} \mathrm{Az}$ emésztő felső részén talált nagyobb vasdarabok és vassalakok valószínúleg már a palota rommá válását követően kerültek az emésztőbe. A fémtárgyak nagymértékủ pusztulásának oka valószínúleg az emésztőben felhal-

\footnotetext{
2 Kocsis 2011, 293-301.

3 Kocsis 2008, 369-370, 9.30. a-b. tétel.

4 Rossz megtartása miatt restaurálás közben szétesett.
} 


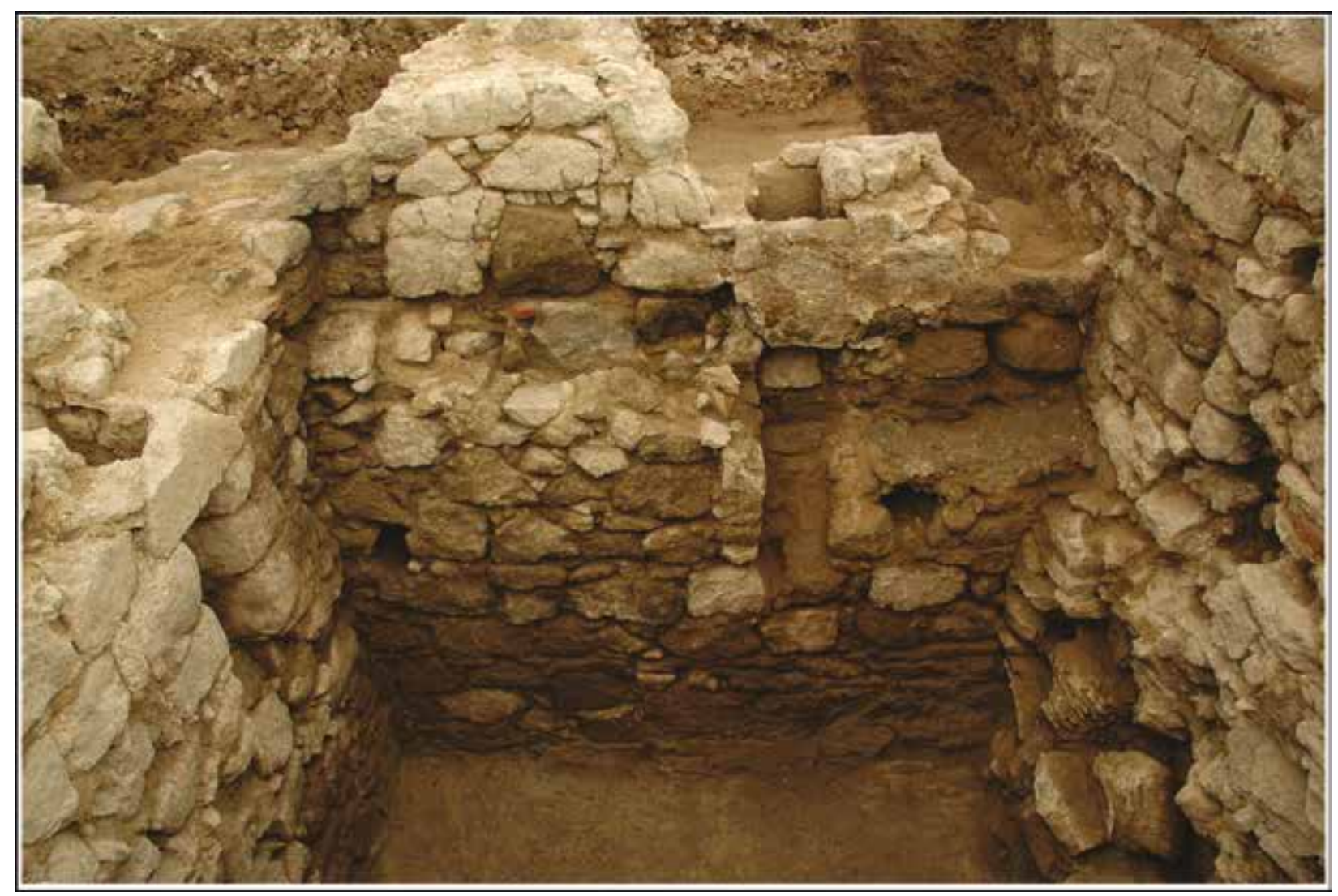

3. kép. Az emésztő északról a két ledobónyílással és a palota nyugati zárófalával

Fig. 3 . The cesspit from the north with the two chutes and the palace's western wall

mozódott szerves anyagok fémekre gyakorolt hatása lehetett.

Mind az elbontott Zsigmond-kori kályhák csempetöredékei (mellettük csak egy kiemelkedő Anjou-kori csempe volt), mind a cserép- és üvegedények darabjai azt mutatták, hogy az emésztó betöltődése a palota Mátyás-kori használatbavételével kezdődött, és a Jagelló-koron át az épületegyüttes 1544-es leégéséig tartott. Összesen négy, a betöltés tetején talált edénytöredéket lehetett a hódoltságkorra keltezni, és akadt még néhány cseréptöredék a 18. századi sváb betelepülés idószakából is. Az emésztőból 216 kerámia- és üvegtárgyat leltároztunk be.

A betöltés mélyebb részeiből azonban - 15 . század végi leletekkel keveredve - előkerült néhány korábbra keltezhető edénytöredék, sőt kiegészíthető edény is. Ezek a darabok még magukon hordozzák az Árpád-kori fazekasság bizonyos jegyeit, illetve az új, gyorskorongolt technikában való gyakorlat hiányáról tanúskodnak. A palotaszárny megépülése után az elsők között kerülhettek az emésztő aljára, ahol meglapultak az 1470-es években végzett tisztítás után is.

\section{Nagy Lajos korából származó edények (4. kép 1-5; 5. kép 1-8)}

\section{Fazekak}

Az emésztő betöltésének aljáról kb. 51 darab, a 14. század közepén kidobott edénytöredék került elő. Közülük 38 tartozott valamilyen főzésre használt kisebb-nagyobb fazékhoz vagy bögréhez. Ezeknek az edényeknek az anyaga - három kivételével - fehér, sárgásfehér vagy szürkésfehér, esetleg halvány rózsaszínes égetett cserép volt. Tíz fazékon lehetett megfigyelni hurkatechnikával felépített edénytestet, csigavonalasan bekarcolt díszítést a külső oldalon, illetve kettős tagolású peremkiképzést. ${ }^{5} \mathrm{~A}$ töredékből egyetlen edényt lehetett kiegészíteni (5. kép 6).

A többi fazék már korongon felhúzva készült, de a korongolás még gyakorlatlan kézzel történt, erről kisebb-nagyobb egyenetlenségek és a külső, díszító bordázás nem teljesen szabályos volta árulkodnak. Az edények általában szúk fenékből kiindulva hordó alakú testtel készültek, a perem-

\footnotetext{
5 Holl 1963, 336.
} 


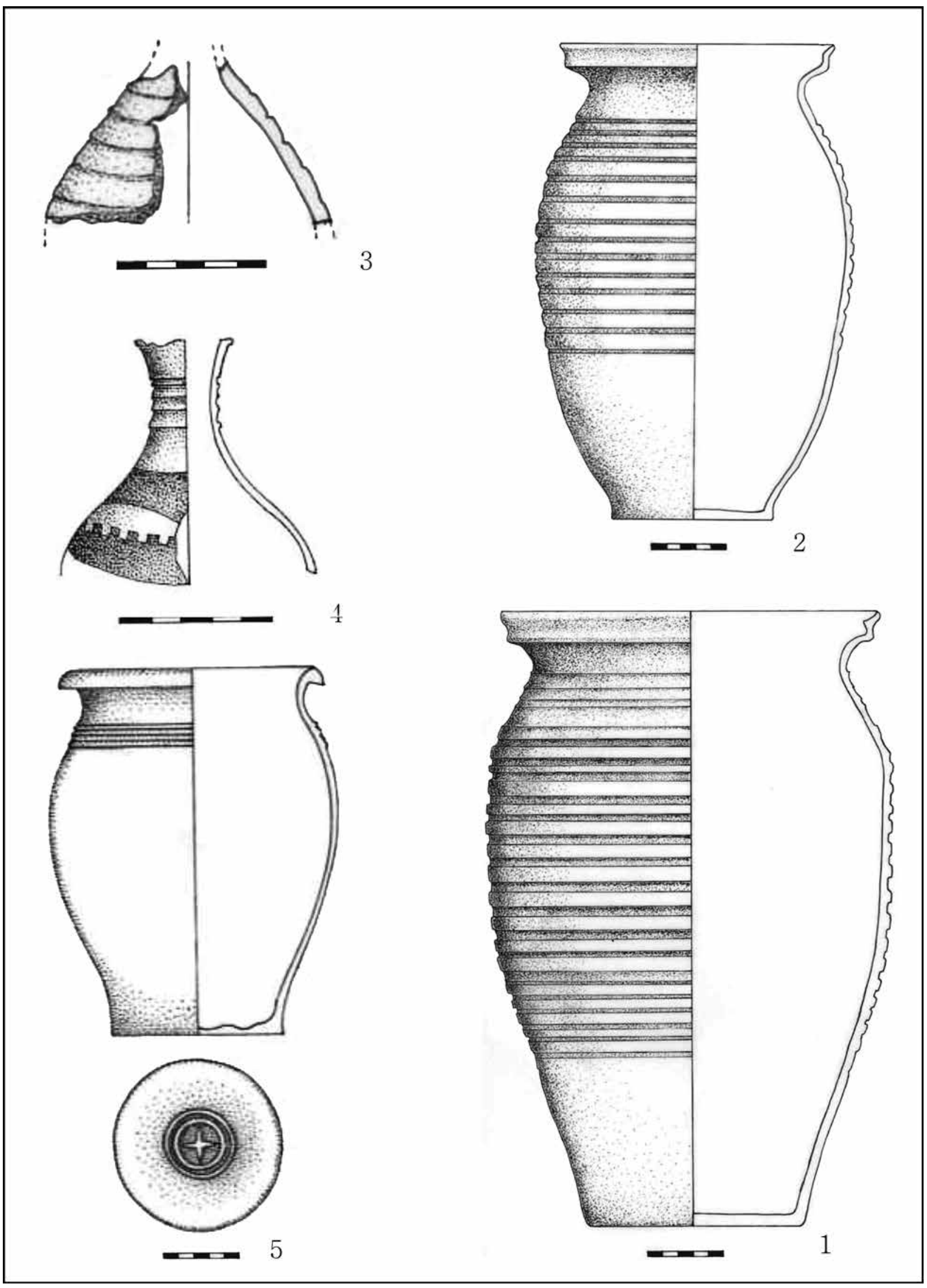

4. kép. 14. századi tárolóedények, palackok és fenékbélyeges fazék

Fig. 4. 14th-century storage vessels, flasks and a pot with a basal stamp 


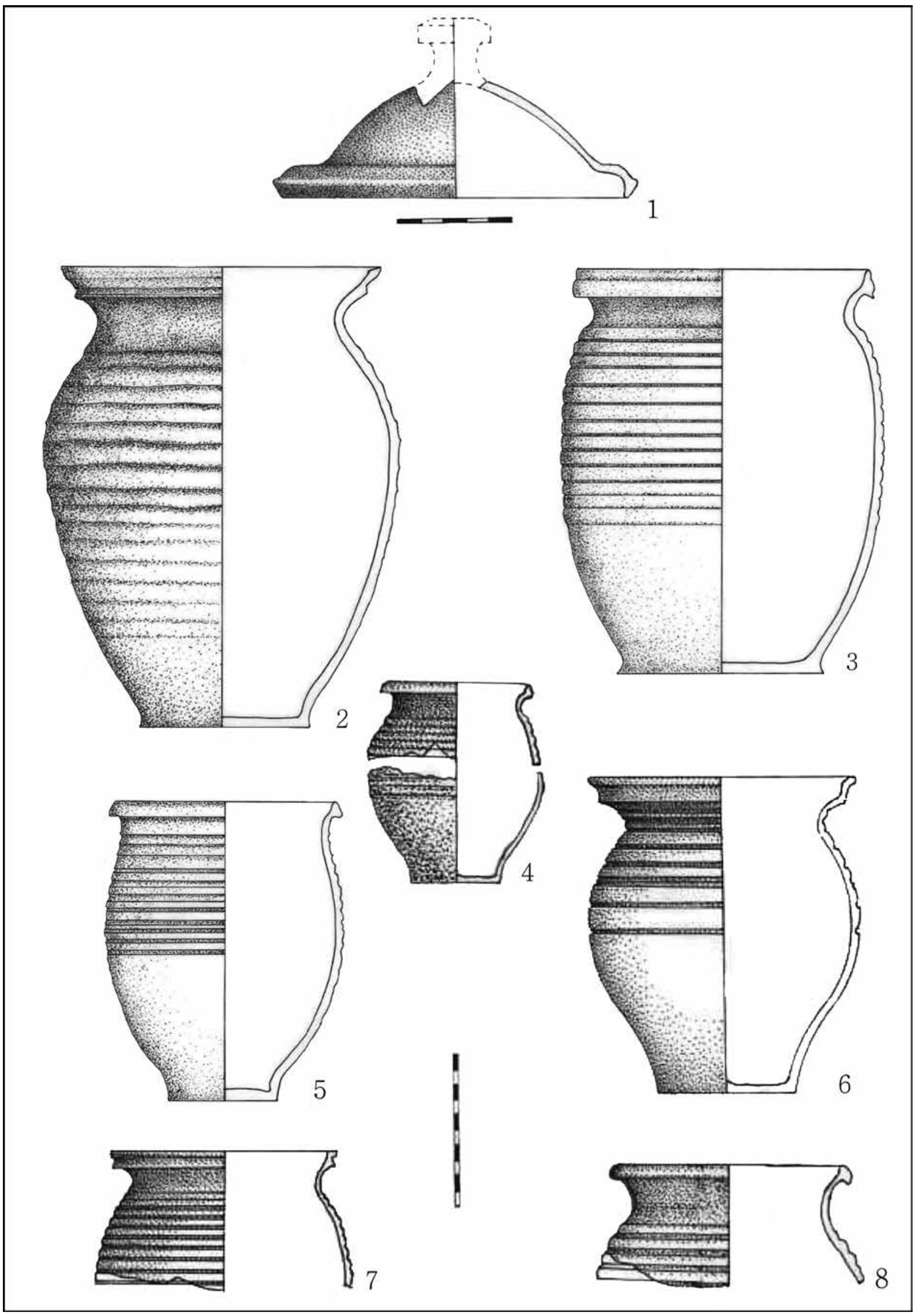

5. kép. 14. századi fedő, tárolóedények és fazekak

Fig. 5. 14th-century lid, storage vessels and pots 
formák között még előfordul a korábbi korszak kettós tagolású kialakítása is (5. kép 7), bár már akadnak megvastagított és háromszögletưre alakított vagy visszahajtva kívül lesimított formák is (5. kép 5, 8).

Különleges figyelmet érdemel egy sajátos kialakítású fazék (4. kép 5). Az edény formailag a korai ausztriai importfazekakra hasonlít, ${ }^{6}$ teste hasas, pereme ennél kissé szúkebb, visszahajló, lekerekített. Vállán két szélesen bevágott mélyedés fut körbe. Fenekén plasztikusan kidomborodó fenékbélyeg: kettős, koncentrikus körbe írt kereszt van. Hasonló, egyszeres körbe írt kereszt alakú fenékbélyeg - ritkán ugyan - előfordul 1314. századi ausztriai importfazekak vagy kancsók fenekén is. ${ }^{7}$ Érdekes az edény anyaga is: szürke, redukált égetésû cserép, de soványító anyagként nagy fehér kavicsok láthatók benne, és felülete is lyukacsosra és matt színúre égetett. Lehetséges, hogy ausztriai importáruról van szó, de anyagát tekintve nem lehetetlen, hogy az osztrák edényeket formailag jól utánzó hazai múhely terméke.

\section{Bögrék}

A bögrék olyan kisméretú, de a túzhelyen használt edények, amelyekben főztek, vagy ételt melegítettek. Általában korongon felhúzva készültek, szúk fenekú, bordázott falú, egyszerú peremkiképzésú darabok. ${ }^{8}$ Fehér, világosszürke és rózsaszín cserépből is akadt néhány példány, de mindegyik darab töredékes (5. kép 4).

\section{Fedők}

Az emésztő anyagában egyetlen 14 . századi típusú, harang alakú, $16 \mathrm{~cm}$ átmérőjú, szürkére égett anyagú fedő töredéke maradt meg - valószínúleg ausztriai importáru (5. kép 1).

\section{Tárolóedények}

Több nagyméretú, fehér vagy sárgásfehér anyagú, fazék alakú tárolóedény töredéke volt az emésztő alján. Közülük négy edény teljesen kiegészíthetó volt (4. kép 1-2, 5. kép 2-3). Ezek az edények is még a hagyományos technikával, agyaghurkákból felépítve, kézi korongon jól elsimítva készültek. Az egyik edény legnagyobb szélessége - a régi formát követve - a vállnál van, pereme kettős tagolású, testét azonban már nem bekarcolt csigavonaldísz, hanem laza bordázás

\footnotetext{
Holl 1963, 340, 12-13. kép.

BENCZE 1992, 215, 5. kép 1; Wien 1981, Katalog 41.

Holl 1963, 343.
}

díszíti (5. kép 2). A többi edény inkább hordó alakú, peremük még szintén kettős tagolású, de testük bordázott vagy hornyolt (4. kép 1-2). Van egy olyan kiegészíthető darab is, amelyet még a hagyományos, bekarcolt csigavonal díszít, de a peremformája "modernebb”, megvastagított, kívül visszasimított (5. kép 3). A fenti jellegzetességek az új, modernebb korongolási és díszítési módokra való fokozatos áttérésról tanúskodnak.

Ezek az edények sosem égettek, nyílt láng felett nem használták őket. Valószínúleg a szomszédos kamrában álltak, leginkább szemes termények, például bab, borsó, lencse tárolására lehettek alkalmasak. ${ }^{9}$ A legnagyobb edény $40 \mathrm{~cm}$ magas, legnagyobb átméróje $26,5 \mathrm{~cm}$, befogadóképessége kb. 8-10 l, míg a kisebb, 21-30 cm magas példányok úrtartalma $\mathrm{kb} .3,5-51$ 1. $^{10}$

\section{Asztali edények: palackok}

Az asztali edényeket két palacktöredék képviseli az emésztő alján megmaradt korai anyagban. Az egyik egy fehérre égetett anyagú, nagyobb méretứ, hurkatechnikával felépített, gömbtestú palack válltöredéke, amelyet sứrú, bekarcolt csigavonal díszít (4. kép 3). ${ }^{11}$ A másik darab egy kis ételízesítós palackocska töredéke, amelyben ecetet, esetleg olajat kínálhattak asztali füszerezésre. A gömbtestú, szúk nyakú, valamivel szélesebb szájú, finom, fehér anyagú edénykét szépen korongolták, testét egy sávban a 14. századtól jellemző, fogazott félkörös mintájú vörös festéssel díszítették (4. kép 4). ${ }^{12}$

\section{Mátyás-kori és 16. század eleji edények (6-12., 14. kép)}

A 15. század utolsó harmadára és a 16. század elejére keltezhető töredékek már az emésztő alján is előfordultak, de többségük a betöltés középső és felső rétegeiből került elő.

\section{Fazekak}

A 15. század végi fazekak sokféle anyagból készültek, és többféle típust képviseltek, ugyanakkor bizonyos anyagú és formájú edények szinte

9 Hasonló tárolóedények a visegrádi palotából: NYÉKHELYI 1994, 165.

10 Az edényeknél a térfogatot legkevesebb félliternyi bizonytalansággal lehetett megállapítani, és a befogadóképesség egymáshoz képest is eléggé eltért, így nem kíséreltem meg az átváltást valamilyen középkori mértékegységre.

11 Holl 1963, 339, 8. kép.

12 Holl 1963,345 

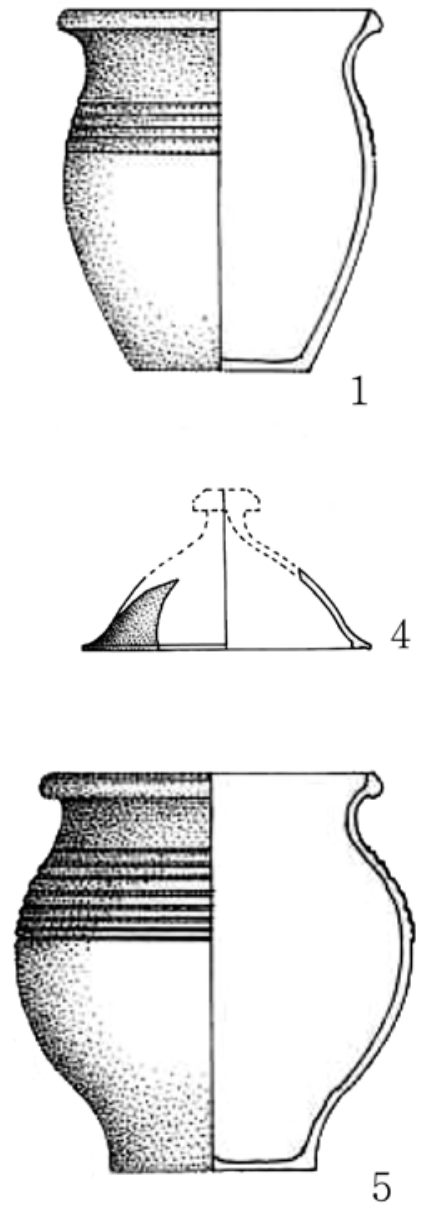

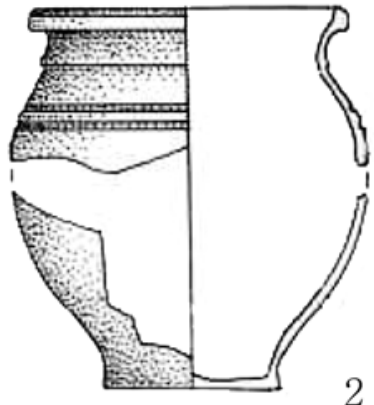

2

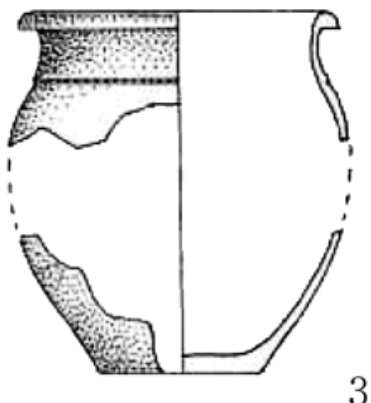

3
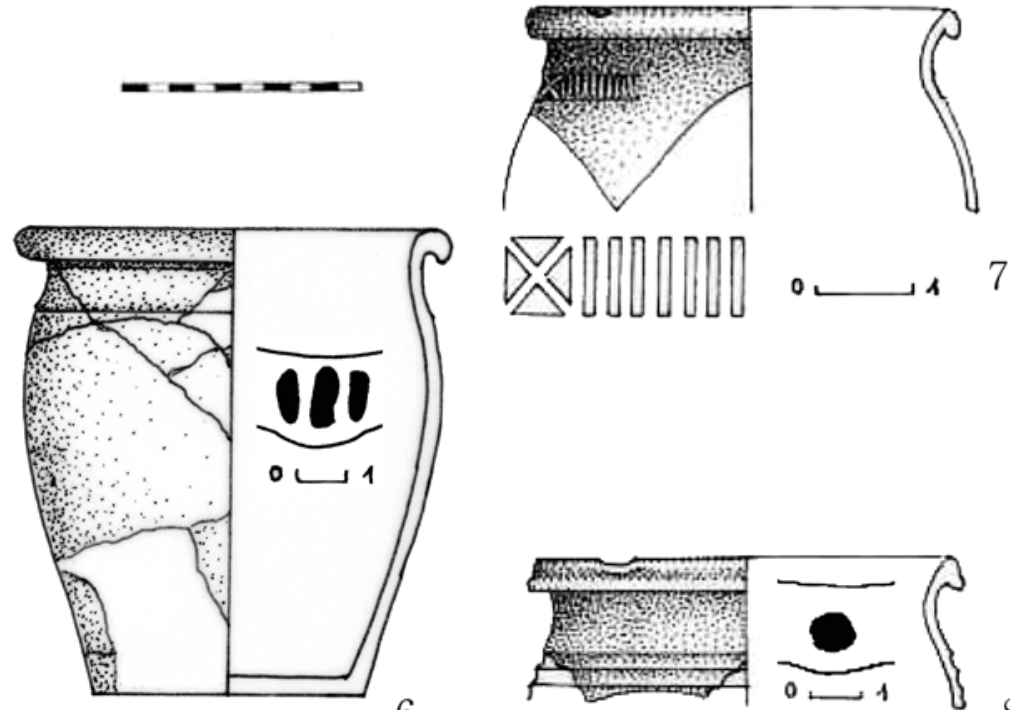

6

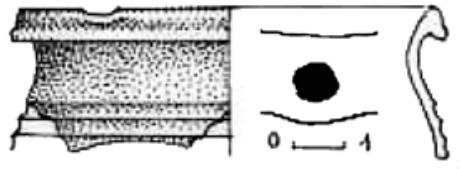

6. kép. 15. századi fazekak, bögre, tárolóedények és fedő

Fig. 6. 15th-century pots, mug, storage vessels and lid

teljesen hiányoznak. A visegrádi palota emésztőjéből csupán egyetlen bögre méretú, túzön sosem használt, vörös cserépból készült, engobe-bal és belül zöld mázzal is bevont edény fenéktöredéke került elő, amely pedig a korszak városi háztartásaiban elég gyakori edény volt. Vörös cserépanyagú, máz nélküli fazék is csupán egy-két darab akadt.

Az előkerült fazekak háromféle anyagúak. Az egyik csoportba a változatosan tagolt peremú, általában bordázott, hornyolt falú, korongon felhúzott, fehérre égetett anyagú, mázatlan edények tartoznak. Ezek csak töredékesen maradtak meg, teljesen rekonstruálható darab nincs közöttük.

A hornyolt díszítésú, sárgásra égetett anyagú fazekak közül három kisebb méretú (6. kép 1-3) és egy nagyobb, hasasabb, a peremre illeszkedő pici füllel ellátott edényt sikerült rekonstruálni (6. kép 5).

A szürkés anyagú, ausztriai készítésú fazekak külön figyelmet érdemelnek. Formailag hasonló típust képviselnek: lapos fenék, vállig szélesedó edénytest, a vállon egy törés vagy körbefutva két, esetleg három bemélyedő vonaldísz, visszahajló, lekerekített perem, amelyet sokszor két helyen bepecsételt perembélyeg is megjelölt. Ezek az edények tették ki a fazekak több mint felét. A kisebb, fazék méretú darabok között kevés a grafittal kevert anyagú, de idetartozik egy kisméretú, bécsi bélyeggel ellátott darab is (7. kép 3). A fazekak többsége anyaguk szerint két alcsoportba osztható: (1) matt, világosszürke, egységes anyagú csoport és (2) sötétszürke felületú, de világosabb törésfelületú edény.

$\mathrm{Az}$ első alcsoportba tartozó, világosszürke anyagú fazékból három darab volt az emésztő leletanyagában. Egy vállán két hornyolattal díszített, bélyeg nélküli példány (7. kép 9); egy hasonló díszítésü zömök fazék két egymással szemben benyomott, pajzs alakú, „, $T^{\prime \prime}$ betút formázó tullni bélyeggel (7. kép 5); valamint egy díszítetlen darab, peremén két ovális, benyomott bélyeggel, amelyet 

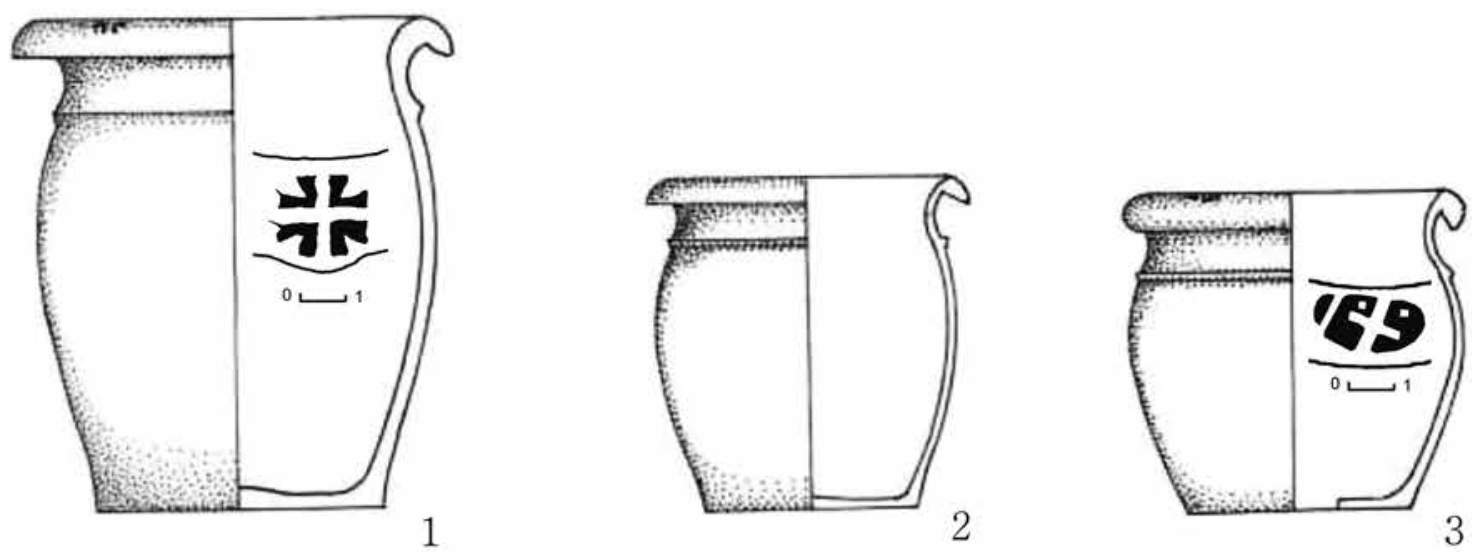

3
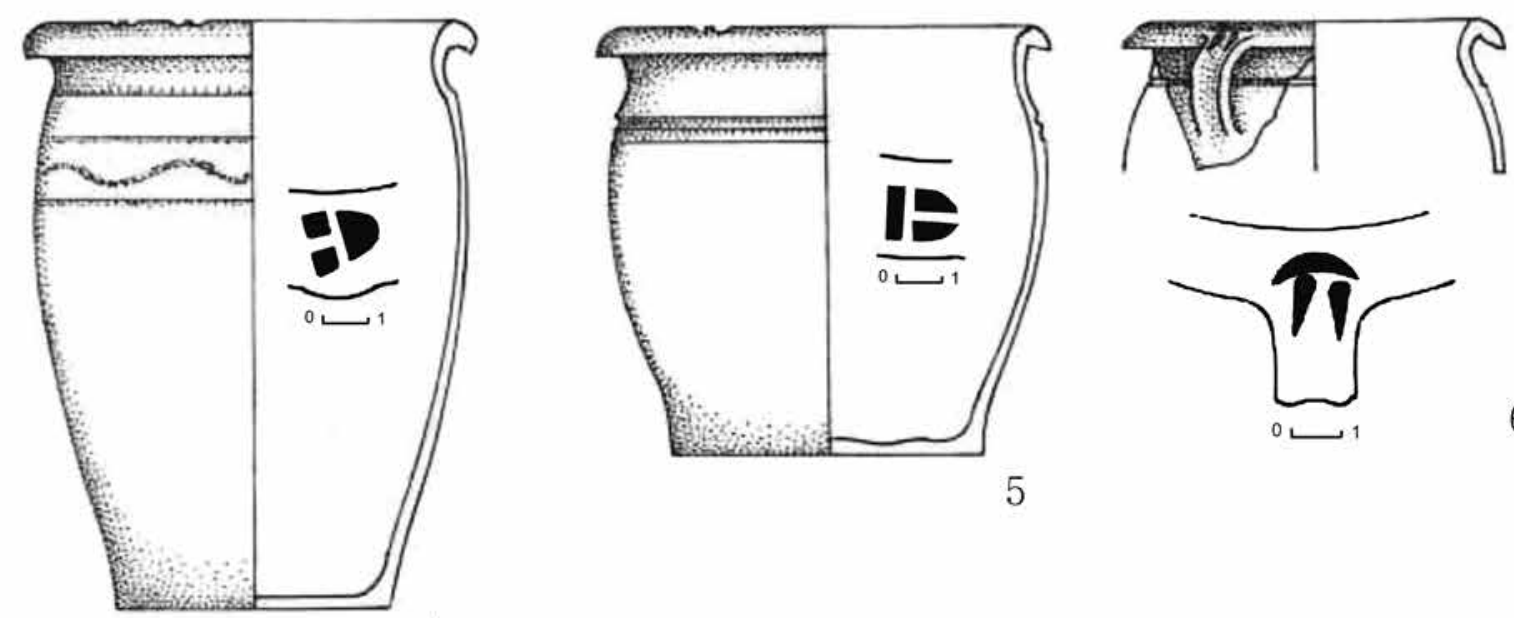

4

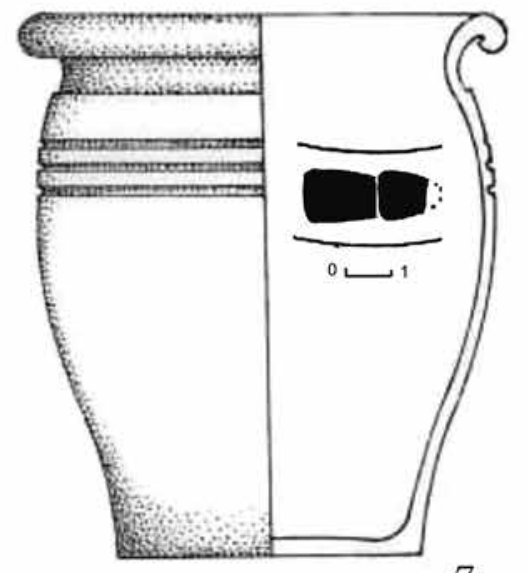

7

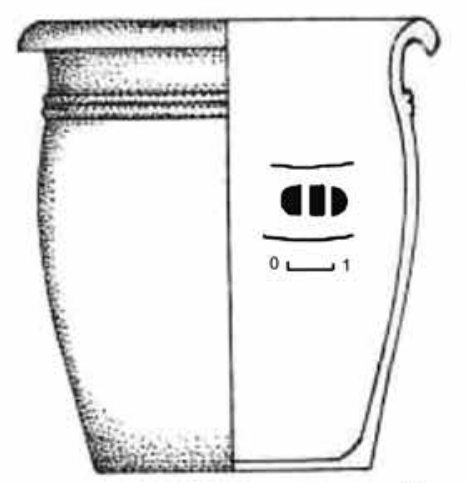

8

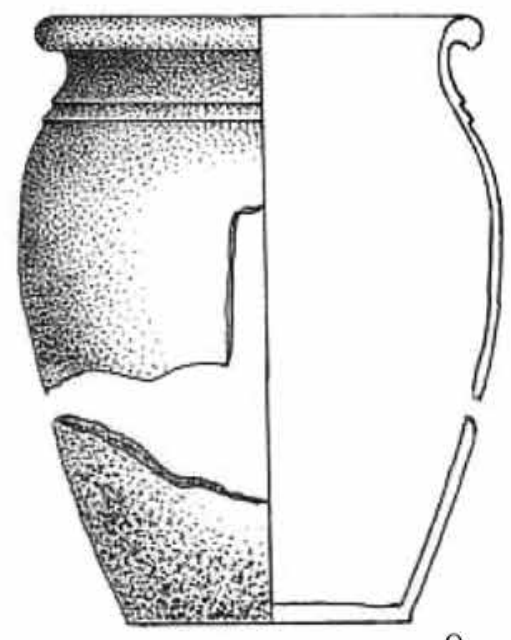

9

7. kép. 15. századi osztrák importfazekak

Fig. 7. 15th-century Austrian import pots 


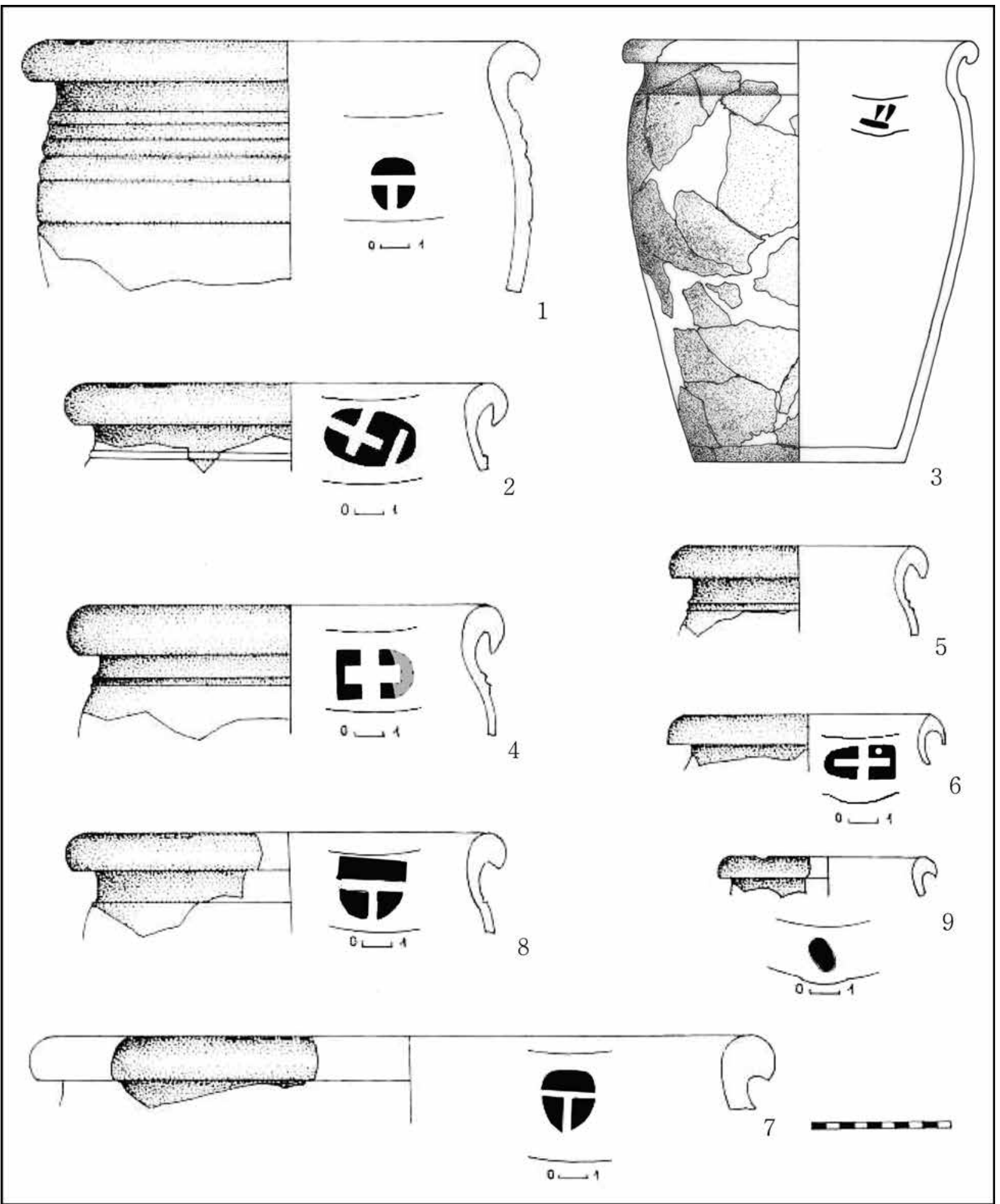

8. kép. 15. századi osztrák tárolóedények

Fig. 8. 15th-century Austrian storage vessels

két sáv oszt három részre (6. kép 6). Ez utóbbi ismeretlen perembélyegú darab azért is különösen érdekes, mert noha a fazék agyagába nem kevertek grafitot, az edény fenekének külső felülete grafitszemcséktől csillog. Ezek valószínúleg úgy ke- rülhettek rá, hogy a múhelyben, ahol a fazék készült, grafitos edényeket is készítettek, s a korongot (vagy az edényszárításra használt deszkát) belepő finom grafitpor ráragadt a fazék fenekére. Mindhárom fazék kb. 21 térfogatú volt. 
A másik alcsoport sötétszürke felületú, világosabb színú törésfelületú darabjainak mérete, díszítése, perembélyegei és talán származási helyei is sokkal változatosabbak. A kisebb edények között volt bélyeg nélküli darab, de füles, bevágással kialakított bélyeggel megjelölt példány is. Ürtartalmuk kb. egyliternyi volt (7. kép 2,6). A nagyobb, nyújtottabb edények közül az egyik vállán két bekarcolt vonal között hullámvonal-díszítés van, és peremén lekerekített pajzs alakú, fordított " $\mathrm{T}$ " alakot formázó, feltehetóen tullni eredetú bélyeg látható (7. kép 4). Egy másik, díszítetlen példányon kerek, kereszt alakú, tagolt bélyeg van két helyen is bepecsételve (7. kép 1) ennek származási helye ismeretlen. Más múhely terméke lehet egy, a vállán három hornyolatból álló köteggel díszített fazék, peremén valószínúleg három, trapéz alakú, egymás szélére nyomott jelből kialakított ismeretlen bélyeggel (7. kép 7). A felsorolt edények ürtartalma 2-3 1. Egy kisebb fazékon ismét feltûnik az ovális perembélyeg, amelyet két sáv oszt három részre, de ez a pecsét a fentebb leírtnál sokkal kisebb méretú (7. kép 8). A kiegészíthetô edényeken kívül néhány peremtöredéken is látható jelölés, például ujjbenyomás vagy pajzs alakú, keresztet formázó bécsi bélyeg, egyik negyedében kis korongos megkülönböztetó jellel (8. kép 5-6, 9).

\section{Fedók}

A fedőket egyetlen fehér anyagú, kúpos palástú fedő töredéke képviseli ebben az anyagban (6. kép 4), ami a leletek mennyiségéhez képest meglepően kevés.

\section{Tárolóedények}

A 15. század végére, a 16. század elejére keltezhető tárolóedények többsége ausztriai készítésú, a fazekak formáját követó darabok gyakran perembélyegesek. Vannak azonban vélhetóen helyi, esetleg nyugat-magyarországi készítésú, fehér anyagú, nem kormos töredékek is, amelyek szintén tárolóedényekhez tartozhattak. Az egyik ilyen bordázott falú, visszahajló, szalagperemes kialakítású edénytöredéken egy ujjbenyomással kialakított jelölés látható (6. kép 8). Egy másik, legömbölyített peremú darab vállát pecsétlóhengerrel húzott sorminta díszíti (6. kép 7). Ilyen pecsétlőhengerrel készített sorminták inkább redukált égetésú, osztrák eredetú darabokon szoktak megjelenni. ${ }^{13}$ Hasonló díszítésú darabok Budáról és Kőszegről is ismertek.

13 Holl 1955, 176, 52. kép.
Az ausztriai eredetú, redukált égetésú tárolóedények közül csak egy példányt lehetett kiegészíteni. Az edény visszahajló, lekerekített peremén két helyen egymással szemben látható, három kis bevágással ejtett ismeretlen perembélyeg van (8. kép 3). A $29 \mathrm{~cm}$ magas, $25 \mathrm{~cm}$ átmérójú edény kb. 5-7 1 befogadóképességú volt.

További tíz tárolóedény nagyságáról csak a nagyobb perem- és fenékdarabok tanúskodnak. Közülük csupán kettőnek az anyagába kevertek grafitot is. A legnagyobb, tullni eredetú darab pereme kb. $36 \mathrm{~cm}$ átmérőjú, rajta két, egymás mellett elhelyezett, pajzs alakú, " $T$ ” betús bélyeggel (8. kép 7). A többi edény általában $20-29 \mathrm{~cm}$ átmérójú volt. A két tullni bélyeges edény megmaradt váll- és oldaltöredékeit egymás alatt több hornyolt sáv is díszítette (8. kép 1,8). Egy példányon ovális alakú, keresztes-pólyás bécsi bélyeg volt látható (8. kép 2). Ez utóbbi tárolóedényen két pecsétet is elhelyeztek egymás mellett, s valószínúleg az átellenes oldalon is kettó volt. Egy peremdarabon kerek talpú pajzsban egyenló szárú keresztes bélyeg domborodik, ez a tárolóedény valószínúleg passaui eredetú lehetett (8. kép 4). ${ }^{14}$

\section{Nagyméretü mázas tárolóedények}

Az emésztó anyagában két különleges kialakítású, nagyméretú, sárga mázas, kancsószerú tárolóedény darabjait találtuk meg: az egyiket egészben hajították be, a másiknak csak a felső része - válltól felfelé - került az emésztóbe. Az edénytípus Visegrádon nem ismeretlen: a fellegvárban talált darabokat -137 edényt - Tóth Boglárka különítette el. ${ }^{15}$

Az edények anyaga homokkal erősen soványított, sárgásvörösre égetett cserép (a töredékes darab rétegesen égett át, felületén sárgás, belül egy csíkban vörösesebb színt kapott). A nagyméretú, nyújtott testú edények - a fellegváriakhoz hasonlóan - korongon felhúzva, két részből összeépítve készültek, az edénytestet és a szájrészt a nyak és a váll találkozásánál dolgozták össze. Válluk erősen domború, alatta hat hornyolatból álló köteg díszíti testüket. Nyakuk a testhez képest elég szúk, a szájperemet három borda tagolja. A szájrész közepéhez és a váll domborulatához kapcsolódik egymással szemben a két szalagfül. A fülekhez képest derékszögben helyezkedik el a kiöntőcsücsök. A kiegészíthető példány magas-

14 Holl 1955, 183-185. A bécsi, tullni, passaui perembélyegek és egyes ismeretlen eredetú darabok rajzolata nagyon hasonlít a visegrádi darabokhoz, ha teljesen nem is azonosítható velük; a származási helyük jól meghatározható.

15 То́тн 2006, 56-61, 5. kép, 141-167. ábra. 

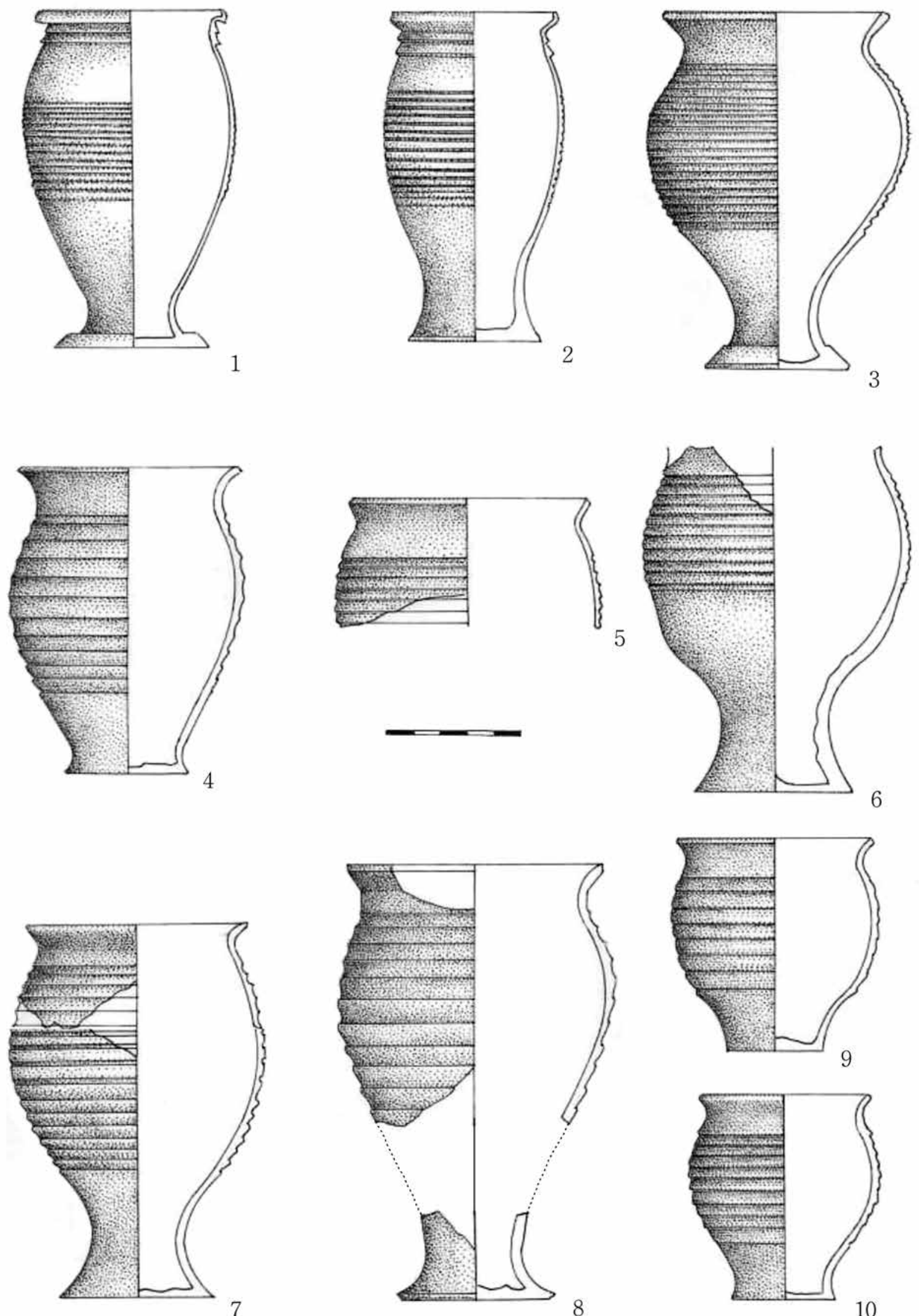

9. kép. 15. századi fehér cseréppoharak

Fig. 9. 15th-century white clay cups 


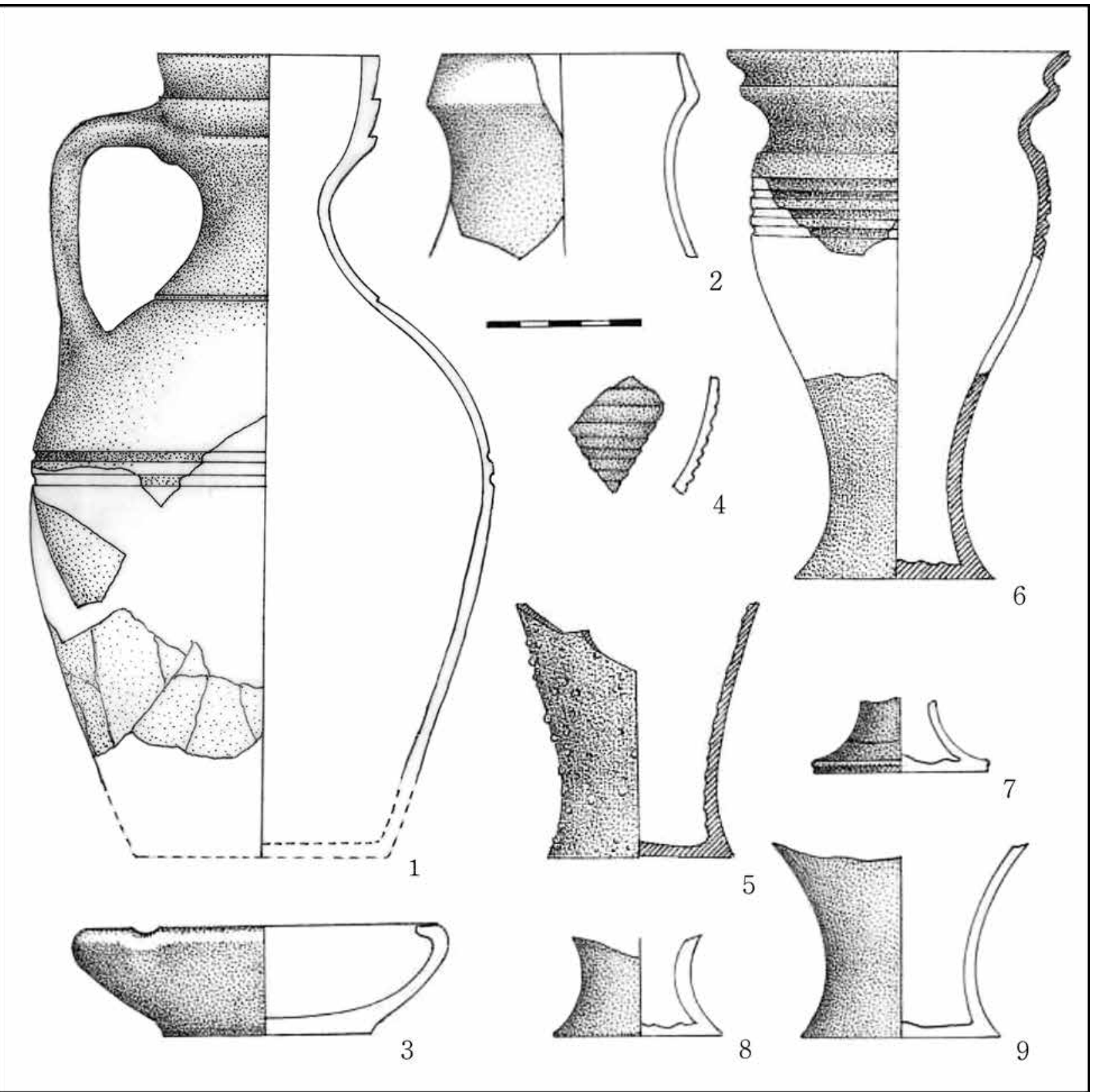

10. kép. 15. századi korsó, kancsó, talpas poharak, mécses

Fig. 10. 15th-century jug, pitcher, footed cups and oil lamp

sága $84 \mathrm{~cm}$, legnagyobb átmérooje $43 \mathrm{~cm}$ (12. kép). ${ }^{16}$ Azon a darabon, amelyiknek csak a felsó része került az emésztóbe (14. kép 1), a vállon egy nagy, korong alakú benyomódás figyelhető meg, amelyről azonban nem lehet eldönteni, hogy ez valamilyen megjelölés, vagy csak véletlenül alakult ki.

A visegrádi fellegvárban talált tárolóedénytöredékek típusa és anyaga nagyon hasonló, inkább díszítésmódra mutatnak nagyobb változatosságot. Mivel az edényeknek sem Magyarországon, sem külföldön nincsenek pontos pár-

16 Kocsis 2010, 386, 30. kép. huzamai, lehetséges, hogy helyi felhasználásra, rendelésre készültek talán még a Zsigmondkorban. Egyes technikai jegyek arra utalnak, hogy készítójük nyugatról, talán osztrák területről érkezhetett. A visegrádi palota ásatásai során is fel-felbukkan ilyen edények néhány töredéke, de inkább a Mátyás-kortól a palota pusztulásáig keltezhetô rétegekben. A palotai emésztőbe került példányokat is a fellegvárból hozhatták le a királyi palotába, ahol a 15 . század végén is használatban voltak.

A Mátyás-korban - véleményem szerint - e nagyméretú kancsókat borvegyítő edényekként 


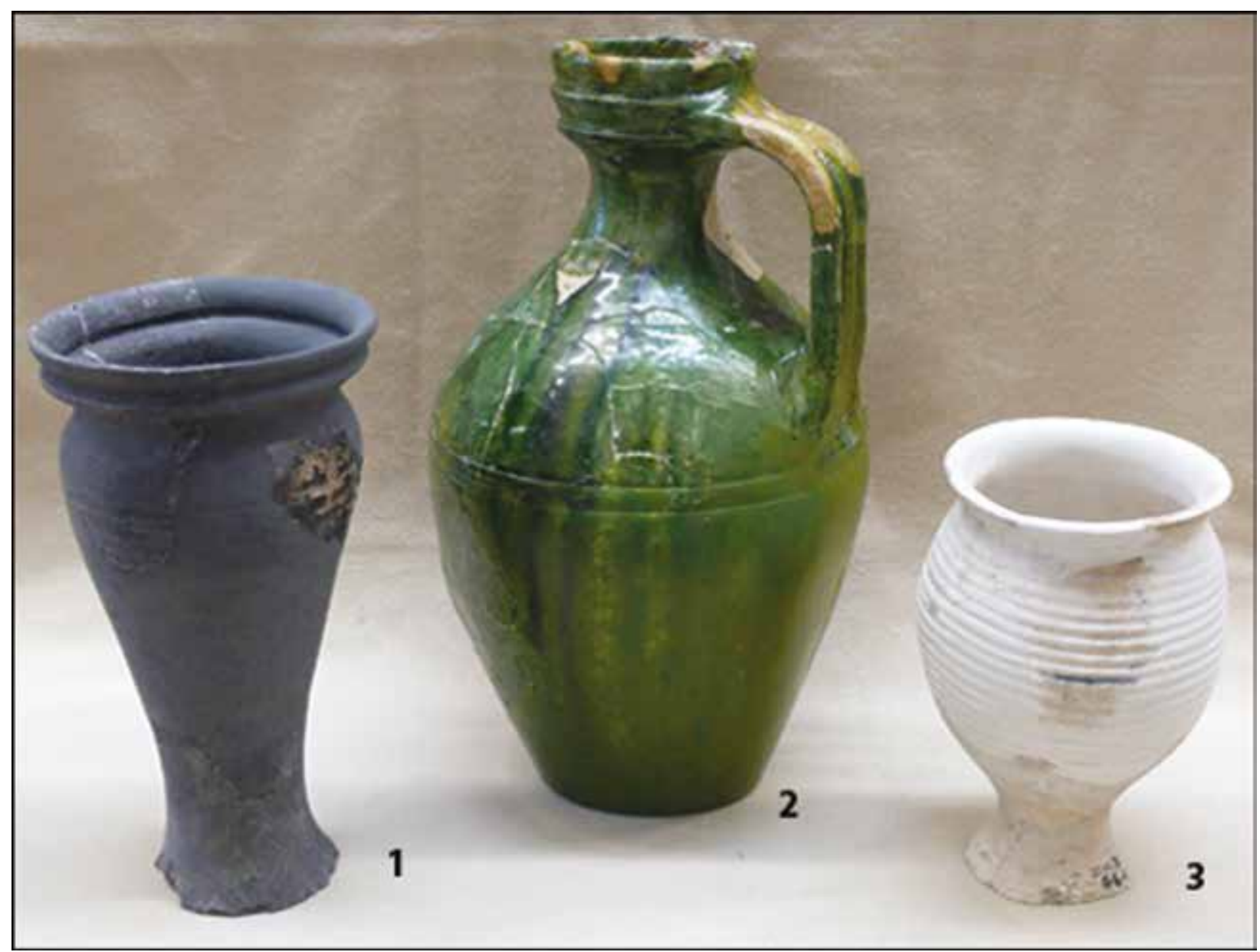

11. kép. 1: osztrák talpas pohár; 2: mázas korsó; 3: fehér talpas pohár

Fig. 11. 1: Austrian footed cup; 2: glazed jug; 3: white footed cup

hasznosíthatták lakomák alkalmával: a pincéből felhozott borokat felszolgálás előtt ezekben keverték vízzel és tárolták az egyik sarokban. Hasonló, szúk fenekú és szájú, de öblös edényeket leginkább a középkorból fennmaradt „kánai menyegző" ábrázolásokon lehet látni, így Jacopo Torriti freskóján Assisiben, a San Francesco felső kápolnájában, ahol az is látható, ahogy megtöltik ezeket az edényeket (13. kép).

\section{Kancsók, korsók}

A kancsók, korsók közül csak kevés, töredékes példány került az emésztőbe. Egyetlen darabot lehetett közülük kiegészíteni, de a talpa hiányzik. A korsó egy 15. század végén megjelenő formát képvisel. Hengeres száját három éles borda tagolja, nyaka rövid, hirtelen összeszúkülő teste hasas, de a feneke felé nyújtott. A váll domborulatán egy, a hasán két hornyolat fut körbe. Szalagfüle a perem aljához és a vállhoz ízesül.
A sárgás anyagúra égetett korsót kívül-belül fehér engobe-bal vonták be - erre került a zöld máz, amelyet bőven folyattak le a külső oldalon, de a vállon maradtak nagyobb mázatlan foltok. Mázat a korsó belsejének felső részére is csorgattak. A darab jól illeszkedik a Mátyás-kortól divatba jövő mázas korsók sorába, de peremkialakítása mégis egyedi, és a mázazást sem végezték rajta túl gondosan (10. kép 1; 11. kép 2).

$\mathrm{Az}$ emésztőben talált többi folyadéktartó edény töredéke csupán az anyag meghatározására alkalmas. Az egyik legszebb töredék egy hófehér anyagú, finom, besimított felületü kancsó peremtöredéke (10. kép 2). Egy kisebb kancsó vagy korsó szemcsés anyagú, sárgára égetett cserépból készült, szúk talpgyưrúje, hengeres testének és fülének darabjai maradtak meg. Előkerült még két fehér anyagú fenéktöredék, egy vörös anyagú, engobe-os, belül zöld mázzal kiöntött edény talpgyứrúje, továbbá két szürke, redukált égetésú ausztriai kancsó néhány kis darabja is. 
Poharak, serlegek

Az emésztőből összesen 21 pohár töredéke került elő. Közülük 15 darab fehér anyagú talpas pohár és két kis pohárka hazai készítésú, és csak négy töredék volt importáru. Az importdarabok közt kell említeni egy Rajna-vidéki, valószínúleg waldenburgi kőcserép pohár oldaltöredékét, ${ }^{17}$ valamint egy lostitzei talpas pohár talpát (10. kép 4-5). Ugyancsak importáru lehetett két talpas serleg is, amelyek magas talppal, hornyolt vállal és kettősen tagolt peremmel készültek sötétszürkére égetett cserépból (10. kép 6, 11. kép 1). Utóbbiak Ausztriában gyakoriak, ${ }^{18}$ Magyarországnak csak az északnyugati részén terjedtek el, így Pozsonyból ${ }^{19}$ közöltek ilyen darabokat. Budán tudtommal - nem fordult elő ez a típus, Visegrádon is ezek az első ismertté vált példányok.

Az emésztőből előkerült hazai gyártású cseréppoharakat négy csoportba lehet osztani. Kettő közülük alacsony pohárka, kis fenékkel, széles, bordázott testtel, egyszerú szájkiképzéssel (9. kép 9-10). Ürtartalmuk kicsi, nem bizonyítható, de elképzelhető, hogy égetett szesz fogyasztására szolgáltak.

Két kisebb talpas pohár enyhén hordó alakú, majdnem hengeres testtel készült. Szájuk finoman tagolt kiképzésú. Egyikük anyaga olyan vékony, hogy már "tojáshéj” pohárnak nevezhető. Ezekbe kb. 2 dl folyadék fért (9. kép 1-2).

12 pohár a hirtelen szúkülő talpú, nagyon szúk szárú, erőteljesen kiöblösödő testú és egyszerú, tagolatlan peremú típushoz tartozott (9. kép 3, 5-8, 10. kép 7-9, 11. kép 3). A poharak befogadóképessége is közel azonos volt: kb. $4 \mathrm{dl}$ fért beléjük. Ez a középkorban nagyjából egy meszelynek, vagyis fél budai iccének felelt meg. ${ }^{20}$ Ezek a poharak nyilván sorozatban készültek erre a méretre, és valószínúleg bort ittak belólük.

Egy további egyszerú, bordázott falú pohár nem sorolható a talpas poharak közé, bár befogadóképessége nagyjából azonos lehetett velük (9. kép 4).

Feltúnő, hogy nagyon kevés díszkerámia, kőcserép pohár került eddig elő a visegrádi királyi palotában. Ennek oka az lehet, hogy az udvar előkelőségei drága fémpoharakból ittak, ezek azonban együtt utaztak a folyton úton lévô udvarral, nem a palota készletéhez tartoztak. Az egyszerú cseréppoharakat viszont a palota kiszolgáló személyzete használhatta, s így kerülhettek nagy számban az emésztóbe.

\footnotetext{
17 Holl 2006, 254-255.

18 WIEN 1981, Katalog 81.

19 POLLA 1979, 127, obr. 65-66, tab. VIII. 1-12.

20 BOGDÁN 1991, 241.
}

Mécsesek

A kerámiából készült világító eszközök közül egy piszkosfehérreégetettanyagú, háromkanócos mécses darabjai kerültek eló. A lapos tálka formájú, vízszintesen behúzott és mélyen aláhornyolt peremú darabon három széles, ujjal benyomott kanóccsücsök látszik. A tárgy belseje középen erősen átégett, ráégett az olaj is, és az egyik kanóccsücsök mellett kormos (10. kép 3).

\section{Kályhacsempék, kályhaszemek}

A Mátyás-korban feltöltődött emésztőből késő Zsigmond-kori, az 1420-as években épített kályhák csempedarabjai kerültek elő. Egyikük egy barna mázas mesejelenetes csempe részlete a

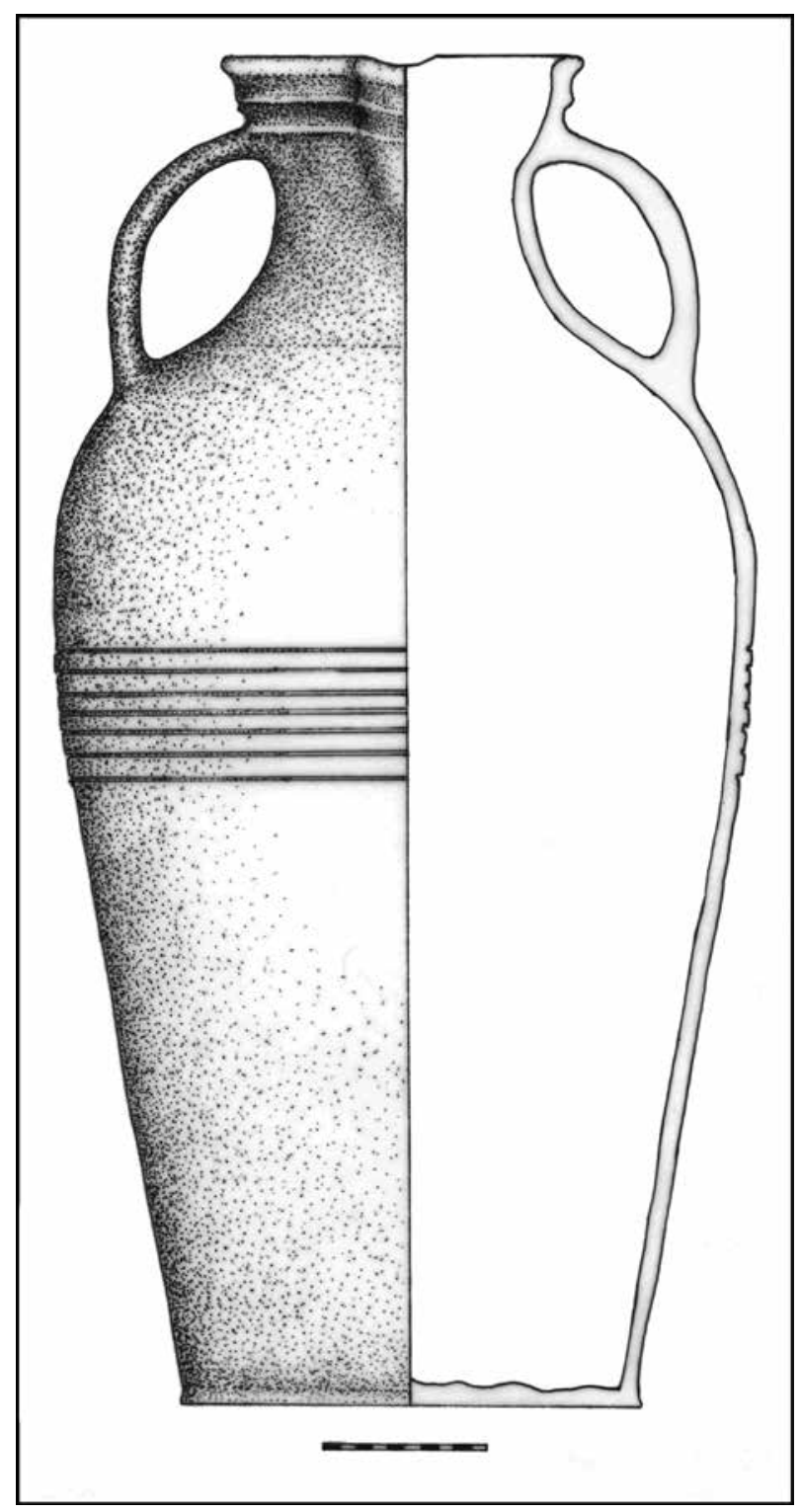

12. kép. 15. századi kancsó alakú tárolóedény

Fig. 12. 15th-century jug-shaped storage vessel 


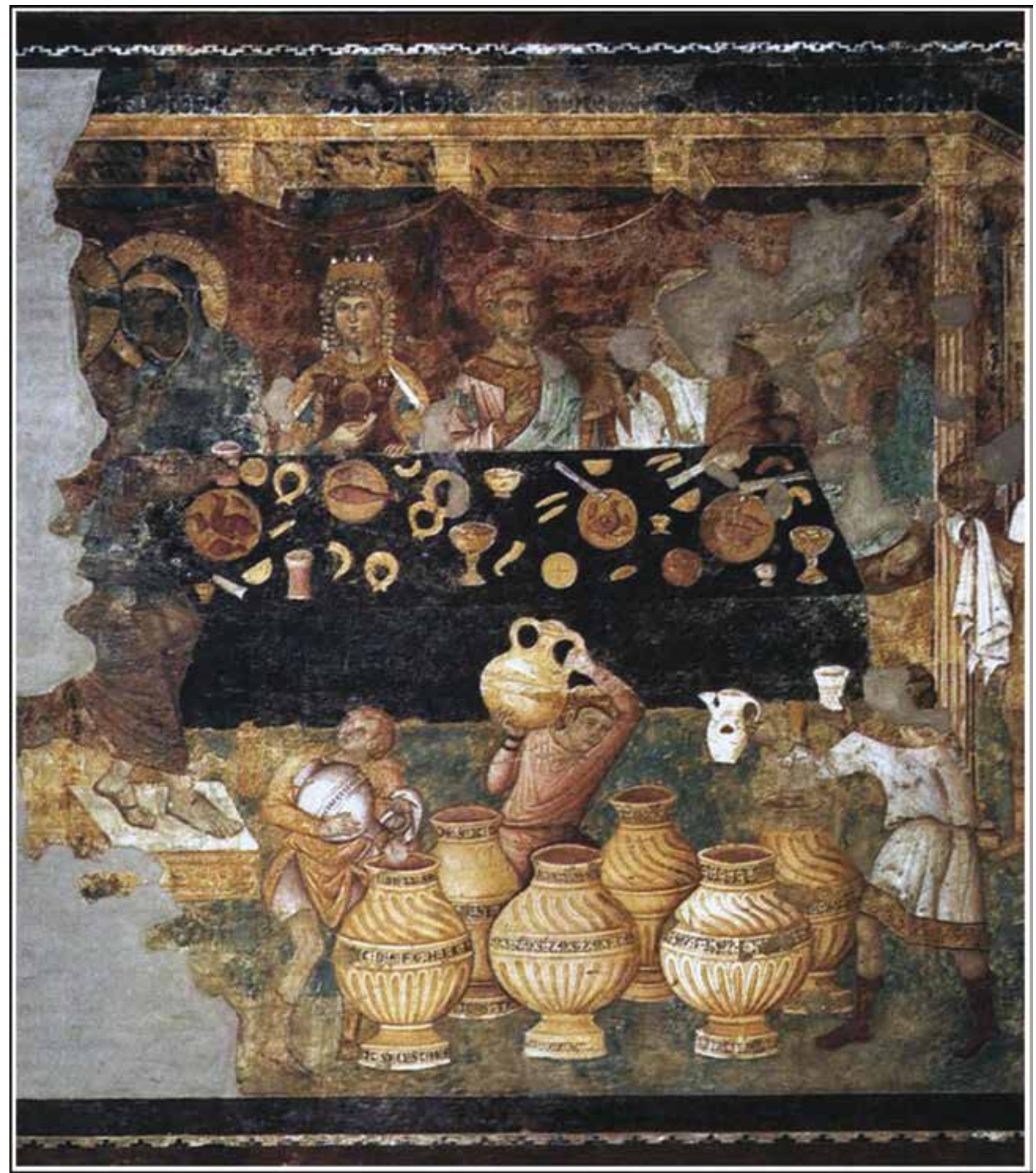

13. kép. Jacopo Torriti: Kánai menyegző. Freskó Assisiben, a San Francesco-kolostor felső kápolnájában

Fig. 13. Jacopo Torriti: Marriage at Cana. Fresco in the Upper Church, Basilica of St. Francis of Assisi, Assisi

sünnel (késő Zsigmond-kori III/4. típus). Egy másik darab pedig ugyanezen múhely négyzetes csempéjének fiókos hátrésze, lefolyt zöld mázzal. Egy zöld mázas tetejú kályhaszem is ebből a korszakból való. Ezek a darabok a palota Mátyáskori átalakítása, felújítása idején az addig álló kályhák elbontásakor kerültek szemétre.
Meglepő az a szinte egészben előkerült csempe - egy Anjou-kori négyzetes darab -, amely ugyancsak az emésztő Mátyás-kori betöltéséből bukkant elő. ${ }^{21}$ Előlapjának rajzolatából korábban

21 Kocsis 2010, 367-368, 17. kép. 


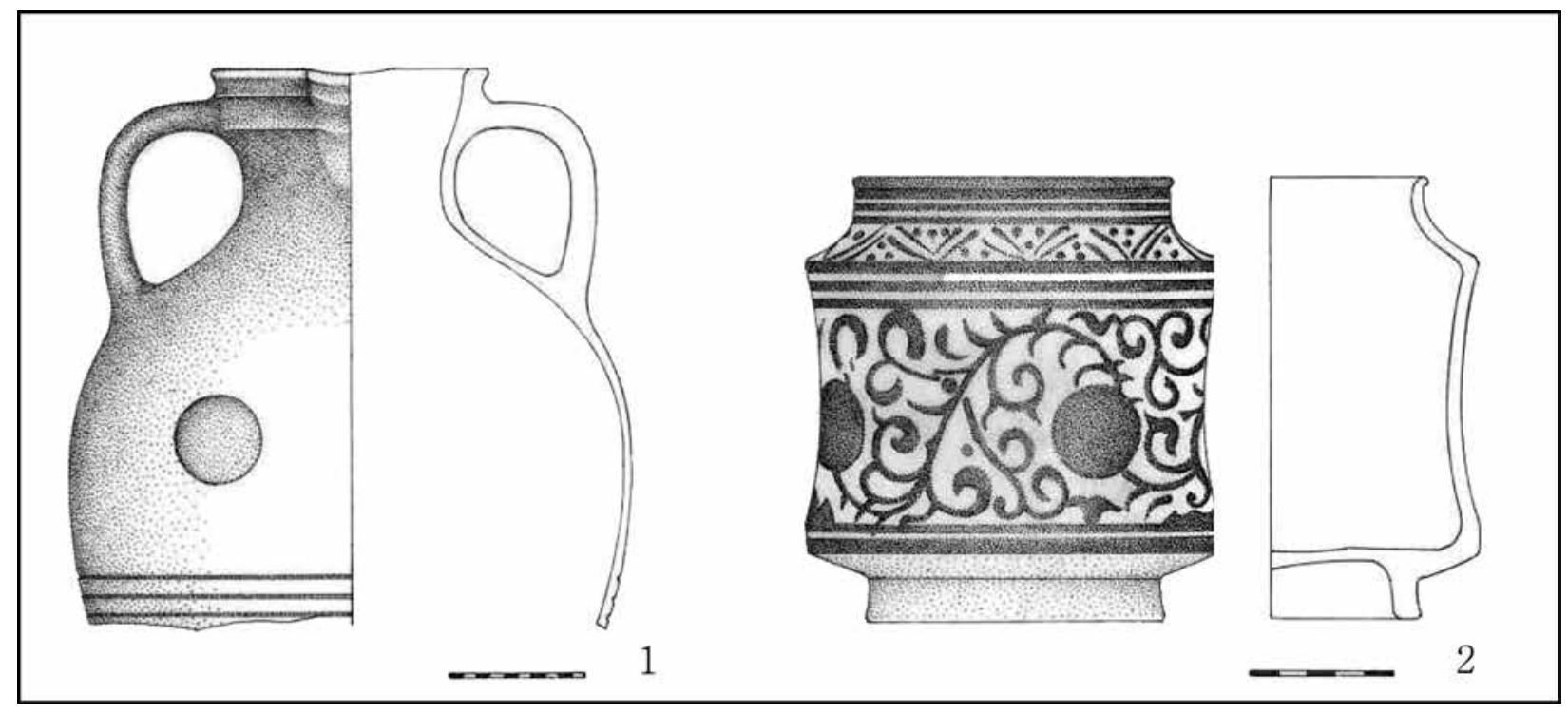

14. kép.1. Kancsó alakú tárolóedény felső része; 2: szíriai eredetú albarello

Fig. 14. 1: Upper part of a pitcher-shaped storage vessel; 2: albarello of Syrian origin

csak a jobb alsó sarkot ismertük, ezt is csak az Anjou-kori I. csoport csempéjének nagyobb méretú változatában - e töredék is a budai várban került napvilágra. ${ }^{22}$ Most azonban a teljes csempeábrázolás ismertté vált: a csempe jobb oldalán a magas kalapos, vadászruhás, övében tőrt viseló hajtó a kürtjét fújja, és pórázon kopókat tart féken, a bal oldalon pedig egy tölgyfán négy madárka ül. (A görbe törzsú fa levelei inkább hársra emlékeztetnek, de a fán mégis makkok teremnek.) A sárgásvörös anyagú, barnászöld mázas csempe $23,5 \mathrm{~cm}$ magas, $22,5 \mathrm{~cm}$ széles, és léckeretét belül homorú vájat tagolja (15. kép). A csempe kisebb méretú a budai darabnál, az Anjou-kori II. csoport másolat csempéi közül való. Ez a kályhásmúhely az 1350-es években készített kályhákat a visegrádi palotába. Az ábrázolás feltehetően egy vadászjelenetes képsorozat része, hozzá tartozik egy fát és koronás oroszlánt, valamint az oroszlán elejtésének jelenetét ábrázoló csempe. Talán egy solymászt ábrázoló csempe is tartozhatott a sorozathoz - ilyen csempe a múhely termékei közül Esztergomban került elő. ${ }^{23}$

Ennek az Anjou-kori csempének a Mátyás-kori betöltésben való előbukkanása azért volt meglepó, mert az Anjou II. múhely kályháit valószínúleg még Lajos király korában elbontották. Véleményem szerint a csempe úgy vészelhette át az emésztőbe kerüléséig tartó időszakot, hogy a bontás után is épen maradt csempét félretették, hogy majd később újra felhasználják egy új kály-

22 Holl 1958, 218, 21. kép.

23 BoldizsÁr 1999, 282; Boldizsár 2003, 103, 1. kép. ha kevésbé látható részén. Ez meg is történhetett, amikor a késő Zsigmond-korban ugyanilyen méretú, $23 \times 23$ cm-es csempékkel építettek kályhát. Így ezt a csempét a Zsigmond-kori darabokkal együtt dobták ki - egészben az emésztóbe.

Ugyancsak a Zsigmond-korból származhatnak azok a négyszögletes tál alakú, redukált égetésú, szürke kályhaszemek, amelyeknek néhány töredéke is bekerült az emésztőbe. A kályhaszemek pereme vízszintesen, sarkosan lemetszett, élhosszuk $23 \mathrm{~cm}$.

\section{Albarello}

A legkülönlegesebb és legértékesebb tárgy az emésztő Mátyás-kori feltöltésének leletei között egy kék-fehér díszítésú patikaedény volt. ${ }^{24}$

A 15,2 cm magas, 14,1 cm átmérójú edény alacsony talpgyưrứn áll, hengeres teste enyhén kónikus, válla csapott, felálló pereme lekerekített végú. A vastag falú tárgy anyaga erősen szemcsés soványítású, fehérre égetett keménycserép. $\mathrm{Az}$ edény testét kobaltkékkel festett növényi ornamentika, vállát és peremét pedig geometrikus minta díszíti. A növényi díszítést négy ovális folt - valószínúleg stilizált virág - alkotja, amelyeket vékony, leveles, kacsos, "S" alakban ívelődő indák kötnek össze. Ezt a motívumot az edénytest alján két, a tetején három festett csík fogja közre. A vállrészt kettős pálcikákkal kirajzolt cikcakkvonal tagolja, az így keletkezett háromszögeket egy, két vagy három pont díszíti. Az albarello

24 Kocsis 2011, 293-301. 


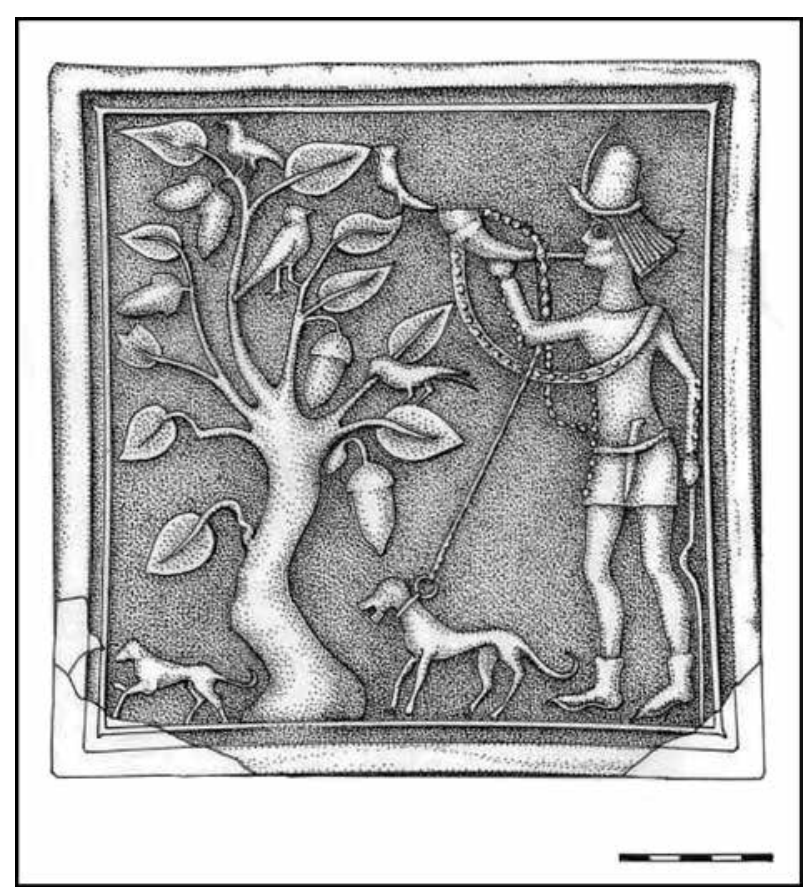

15. kép. Anjou-kori vadászjelenetes kályhacsempe

Fig. 15. Angevin-period stove tile with a hunting scene

száját ugyancsak három kobaltkék csík emeli ki. Az edény teljes belsejét, valamint külsejét az edénytest aljáig vastag, színtelen, átlátszó mázzal vonták be, egyes részeken a máz alatti festés csíkokban elmázolódott. Az edény feneke mázatlan, ső́t néhol az edénytest alsó festett csíkja is fedetlenül maradt. A jó minőségú, bár apró repedéseket mutató máz az albarello belsejében, ahol a mázréteg vastagabb, halványzöld árnyalatúnak látszik (14. kép 2).

$\mathrm{Az}$ edény ritka és értékes importáru volt. Visegrádon kívül csak a budai Várból ismert még néhány hasonló anyagú és mintájú, a máz alatt kékkel vagy feketével festett albarello-töredék Magyarországról. A budai darabokat közel-keleti eredetúnek tartják, és a 14. század második felére keltezik, legkésőbb a 15. század elején kerültek a földbe. ${ }^{25}$

Az emésztőben talált edény másik analógiája, amely nemcsak anyagában és készítés technikájában, de méretében és szokatlan alakjában is megegyezik vele, ugyancsak a visegrádi palotában került elő egy olyan rétegből, amely az 1360 körüli átépítés során elbontott Anjou-kori épületek kidobott kályháit és használati tárgyait tartalmazta. Az orvosságos edény külsejét fekete és türkizkék színnel festett, geometrikus minta díszíti, és kívül-belül ugyancsak színtelen mázzal vonták be. Az edény díszítésének párhuzamai a

25 Holl 1990, 243-246, 3a-c és 35. kép. szíriai Hamában talált 14. századi kerámiákon fedezhetők fel. ${ }^{26}$

A 14-15. századtól a Közel-Keletre áramló, kék-fehér színezésú kínai porcelán nagy hatást gyakorolt a kerámiamúvességre. Előbb Iránban kezdték utánozni, később a kék-fehér színú edények készítésének divatja a Közel-Keletet is meghódította. A díszítőelemek között megjelenő kínai és perzsa eredetú motívumok ötvöződtek a hagyományos mintákkal. Szíriában elsősorban Damaszkusz és Hama volt ekkor a kerámiagyártás központja.

A visegrádi albarellók készítéstechnikájuk, mintakincsük és párhuzamaik alapján Szíriában készülhettek. A geometrikus motívumú edény jellegzetes közel-keleti, hagyományos mintájú, 14 . századi darab, amely az 1340-es években juthatott el Magyarországra, és 1360 körül dobták ki. Az indásvirágos díszú albarello színezésében már a kínai porcelán, mintázatában pedig a perzsa díszítóelemek hatását is tükrözi, díszítésének stílusa kissé későbbi. Ez is Szíriában készülhetett a 14. században vagy a 15. század első felében, és Nagy Lajos vagy Zsigmond király uralkodása idején kerülhetett Visegrádra. A gondosan óvott díszedényt sokáig használták, hosszú időt élt meg, és csak a 15. század végén került szemétre. Ritka véletlen az is, hogy épp két ilyen szokatlan alakú keleti díszedény került a visegrádi palotába. Ha eltérő díszítési stílusuk ellenére mégis egy időben készültek, felvetődhet az a lehetőség is, hogy a geometrikus és a növényi díszítésú edény párt alkotott.

Az albarellók sokféleképpen kerülhettek a magyar királyi udvarba. A különleges, ritka és drága importedények akár diplomáciai ajándékként, akár - nagyobb valószínúséggel - kereskedelmi úton érkeztek Itália valamely városállamán vagy éppen Velencén keresztül, amely a Levantéval folytatott kereskedelmet a kezében tartotta. Erzsébet anyakirályné 1343-as itáliai utazása, de Nagy Lajos király itáliai hadakozásai és diplomáciai kapcsolatai útján is Visegrádra kerülhettek, a növényi díszítésú albarello esetében pedig Zsigmond király számos utazása, szerteágazó diplomáciai tevékenysége is számításba vehető.

\section{Üvegleletek}

\section{Lámpások}

Az emésztő különleges, kiemelkedő jelentőségú leletei között kell említeni a négy üveglámpás darabjait is. ${ }^{27}$ Méretben, minőségben és teljessé-

26 RiIs-Poulsen-Hammershaimb 1957, 223, 770. kép.

27 Kocsis 2008, 369-370, Kat. 9.30a-b. 


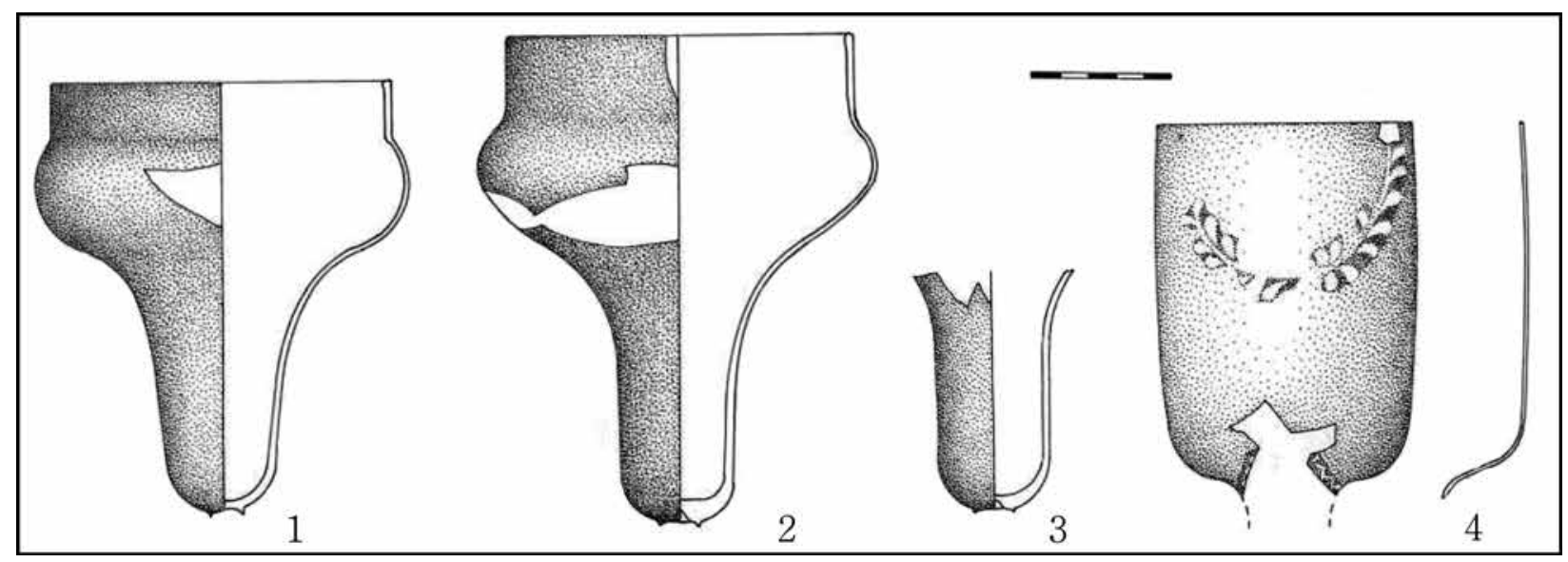

16. kép. Mátyás kori üveglámpások

Fig. 16. Matthias-period glass lamps

gükben is kiválnak a Magyarországon eddig talált - nem túl sok - példány közül. A lámpások két csoportba oszthatók.

Három lámpás azonos anyagú, formájú és szinte azonos méretú darab. Együttes felbukkanásuk azt sejteti, hogy egy csillár részei lehettek, amely talán leszakadt, darabjai így törhettek el egyszerre és kerülhettek szemétre. A lámpások anyaga zöld - a vastagabb részeken sötétzöld -, jó minőségú, a földben is romlatlanul megórződött üveg. Hosszú alsó nyúlvánnyal rendelkező, középtájon szélesen kiöblösödő darabok, de felső végük kissé behúzott, hengeres alakú, a peremnek nincs kihajló vége. A lámpások alsó részén jól látszik a pipa nyoma, ahogy megfogták őket. A legépebb lámpásnak - ma még egyedülállóan - a teljes profilja megvan, de egy másik darab mérete is jól rekonstruálható két nagyobb töredékből. A harmadik lámpásból sajnos csak az alsó nyúlvány maradt meg. A lámpások mérete is jóval nagyobb az eddig előkerült példányokénál: az egyik 15,3 cm, a másik kb. $17 \mathrm{~cm}$ magas, legnagyobb átméröjük 13,3 cm, illetve $14,5 \mathrm{~cm}$ (16. kép 1-3). Hasonló alakú és méretú, zöldes színezésú lámpásokat inkább német területről ismerünk, például Heidelbergből ${ }^{28}$ és Strasbourgból. ${ }^{29}$

Használatuk során az üvegtartályokat olajjal töltötték fel, ebbe állították a kanócot, amelynek felső vége égett, míg alsó vége szívta fel az olajat. Az ábrázolások tanúsága szerint a kanóc függóleges helyzetét egy középen lyukkal ellátott koronggal szabályozhatták. A korong a lámpásban fogyó olaj szintje szerint süllyedhetett, feltöltés után pedig ismét felülre került. Eközben pedig odadörzsölődött a lámpás hengeres részének belsejéhez, kopásnyomokat hagyva rajta, ahogy ez a

28 ObERrhein 2001, Katalog 185

29 ELSASS 1992, 165, Kat. 1.76. legépebb darabon jól megfigyelhető volt. A korong talán egy vékony fémlap lehetett, mivel a fa valószínúleg egy idő után olajjal átitatódva lángra kapott volna.

Csak találgathatjuk a visegrádi lámpások felfüggesztésének módját, mivel magukon a darabokon erre semmi sem utal. Sem fülük, sem kihajló, kiszélesedő peremük nincs, amely alatt egy fémgyưrúvel (esetleg egyenlő oldalú háromszöggel) átfogva egy hármas lánc segítségével általában felfüggesztik őket - ahogy ez a Magyar Anjou Legendárium miniatúráin is látható. Giotto freskóin Padovában és Assisiben több, csillárszerúen felfüggesztett lámpást ábrázol. A padovai Scrovegni-kápolna diadalívének két oldalán egy-egy boltozatos térben függóleges pántokból és vízszintes gyưrúkbból álló konstrukciót látunk; egy-egy gyưrúről általában háromhárom lámpás lóg le. Jól megférnek egymás mellett különböző lámpások, köztük a visegrádiakhoz hasonló, de felső részükön jobban kiszélesedő darabok is.

A visegrádi lámpások pereme azonban nem alkalmas ilyen módon való felakasztásra. Látszólag csak egy mód kínálkozik a felfüggesztésükre, ha alsó nyúlványukat szúrják valamilyen gyưrúbe vagy foglalatba. Ezek a foglalatok lehettek összekapcsolva egyetlen tartószerkezetté, amelyet felakasztottak. Ilyen csillárokra számos példát találhatunk az 5-6. századtól a Földközi-tenger keleti medencéjében. Hasonló csillárja volt a konstantinápolyi Hagia Sophiatemplomnak, amelyet a New York-i Corn Museum óriz, ${ }^{30}$ de kopt darabot is ismerünk ebból a korból. ${ }^{31}$ A reneszánsz korban is alkalmaztak ilyen megoldást, ahogy ez a Geolfino 16. szá-

30 MAJEWSKI 1968, Kat. 83.

31 WeChSSLER-KüMmEL 1962, Kat. 83., 35. kép. 

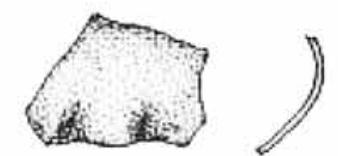

1

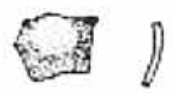

2
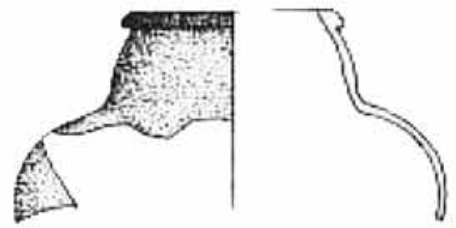

5
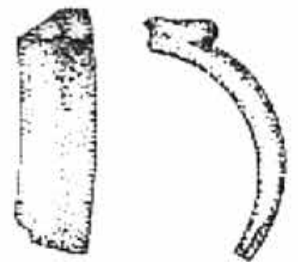

3

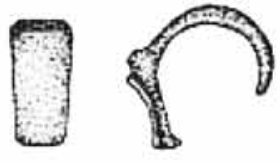

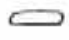

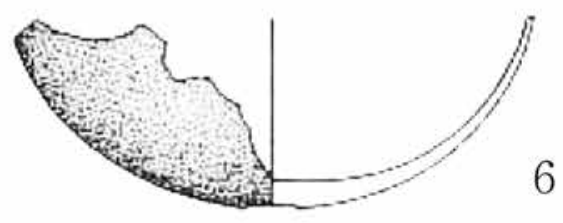

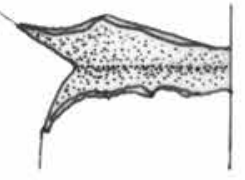
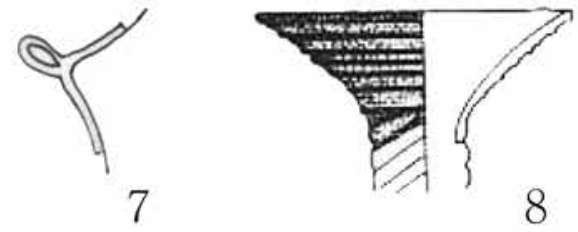

9
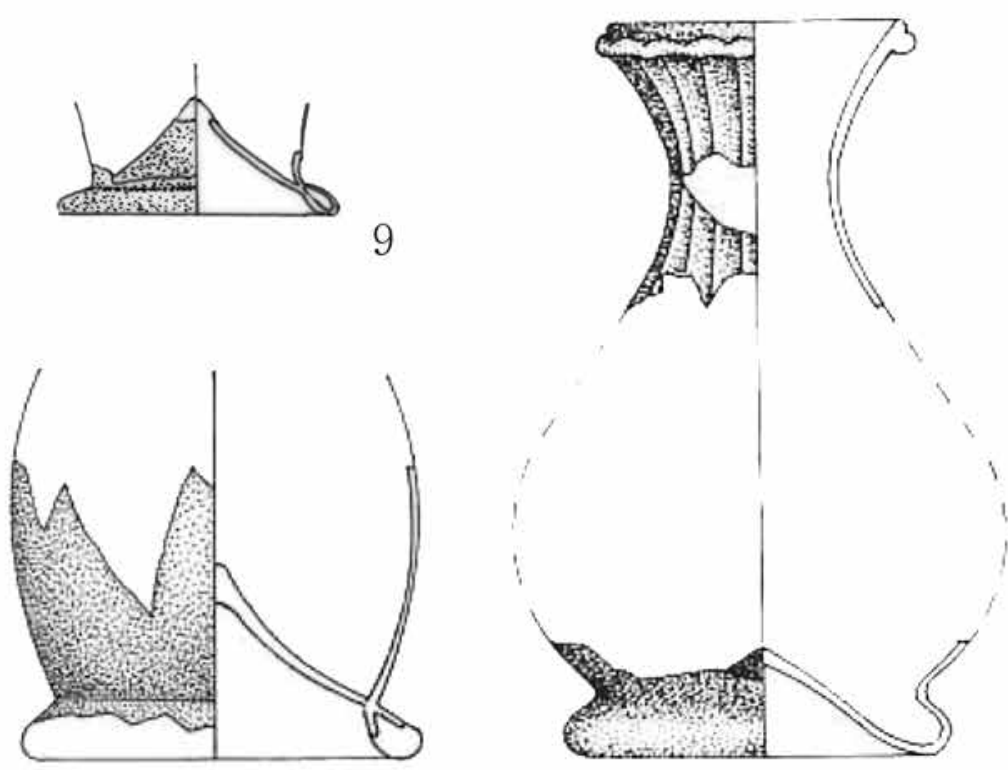

10

11

17. kép. 1-6: 15. századi üvegpohár-töredékek; 7-12: 15. századi üvegpalack-töredékek

Fig. 17. 1-6: fragments of 15th-century glass cups; 7-12: fragments of 15th-century glass flasks

18. kép. 16. századi korsótöredékek és 18. századi edénytöredék Fig. 18. 16th-century jug fragments and the fragment of an 18th-century vessel 


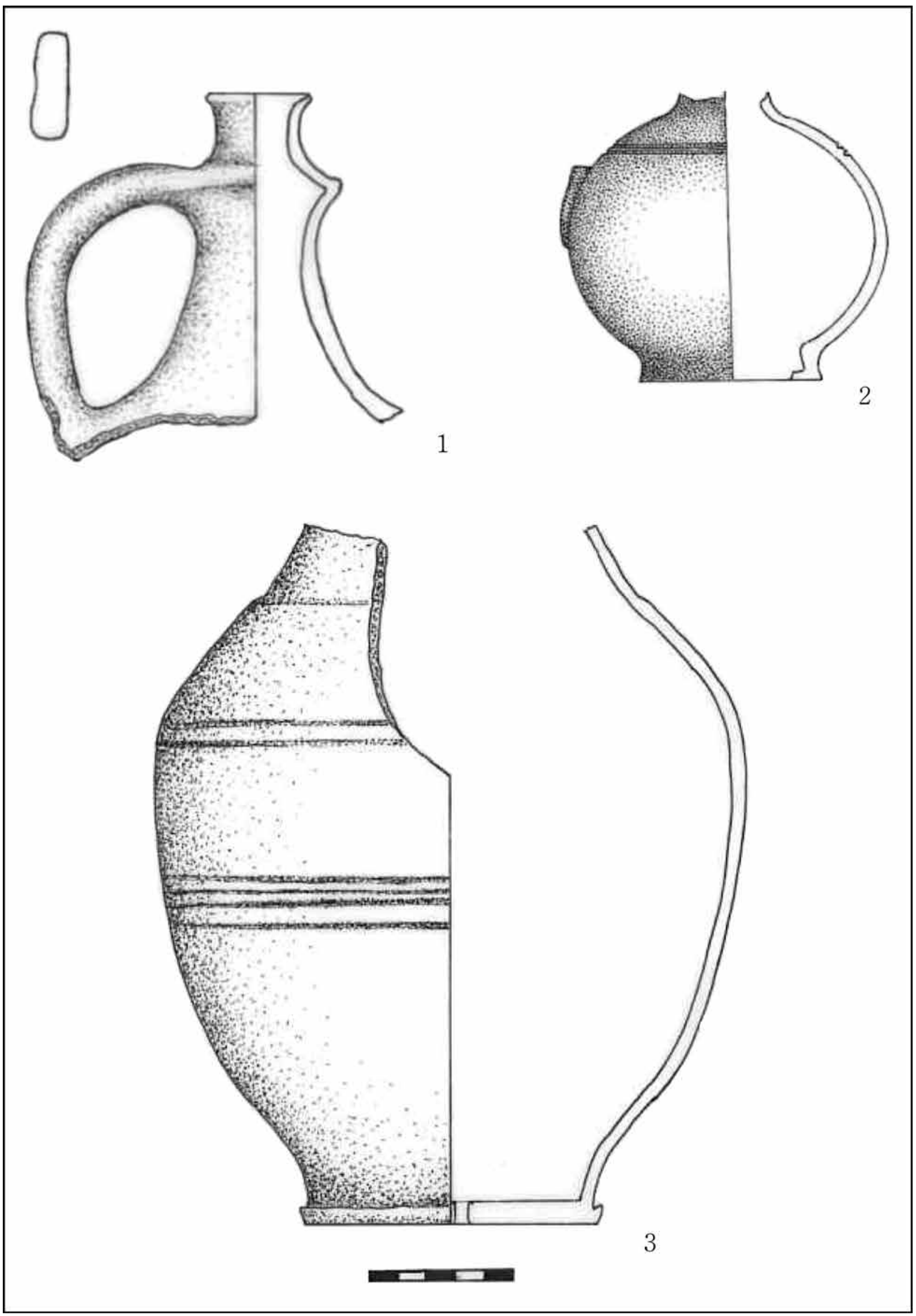


zad közepi freskóján ábrázolt csilláron is látható Veronában, a Santa Maria in Organo-templomban. ${ }^{32}$ Ezt az egyszerú felfüggesztési formát alkalmazhatták Visegrádon is.

Az emésztőból napvilágra került negyedik lámpás másféle típust képvisel. Csak a felső tartály maradt meg, egy hengeres, perem nélküli rész, míg alja ívelten szúkül az alsó nyúlvány felé, amely sajnos letört. Anyaga színtelen, átlátszó, romlatlan üveg, valószínúleg velencei gyártmány. A megmaradt rész magassága $13,3 \mathrm{~cm}$, az átmérő: 9,4 cm (16. kép 4). A hengeres rész egyik oldalát a peremtől félkörben ívelődő festett, aranyozott levélfüzér díszíti. Alatta, a letört nyúlvány vonalában, fordított „U” alakban egy kisebb levélfüzér is fut. A díszítés csak az egyik oldalon jelenik meg, csak erre a nézetre készült. Falikar vagy csillár része lehetett, és a zöld lámpásokhoz hasonlóan nyúlványánál fogva szúrhatták a foglalatába, hiszen más módon nem lehetett volna felfüggeszteni.

\section{Palackok, korsók}

A palackok között különleges figyelmet érdemel egy szúk nyakú, tölcséres szájú töredék színtelen, formába fújt, diagonálisan csavart üvegból, száját kívül kobaltkék, spirálisan rátekert üvegfonaldísz is ékesíti (17. kép 8). Ez a darab egy Velencében készült, a 14. századtól kezdve hoszszú időn át népszerú, ún. „,angastare” palackféleséghez tartozik. (Az edény gömbteste és visszahajtott gyûrû́s talpszegélye elpusztult. ${ }^{33}$ ) A típusból jó néhány darab került már elő Magyarországon is, az egyik legjobb párhuzam éppen Visegrádról való az északkeleti palotaszárnyból, ${ }^{34}$ de több töredék ismert Budáról és Konszegról. ${ }^{35}$ Külföldön is igen elterjedt, találtak „angastare"-t Muranóban, Ingolstadtban, Avignonban, Cividaleban is.

Egyedibbnek tûnik egy függóleges optikai bordázással díszített, tölcséres szájú, széles nyakú, talán enyhén lapított gömbtestú, talpkarimás palack, amelynek három nagyobb töredéke maradt meg. Szájnyílása alatt a függóleges bordázás plasztikusabbá válik, közvetlenül a vége előtt kissé elcsavarodik, a perem pedig egy szépen megformált, vízszintesen csavart bordában végződik. A peremet belül egy egyenetlen szélességú üveggyúrü beragasztásával is megerősítették.

\footnotetext{
32 WeChSSLER-KÜMMEL 1962, 96., 54. kép.

33 H. GYÜRKY 1991, 43-44, 7/b típusú palack, XV. tábla 5.

34 Mester 1997, 13, 20. kép.

35 Buda: H. GYÜRKY 1991, XV. tábla 5, 47-48, 133, 1. ábra. Kőszeg: Holl 1992, 53-54., 23. és 161. kép.
}

A talpkarima belül nyitott, nem hajlik vissza teljesen (17. kép 11). A palack velencei minőségü, színtelen üvegból készült. Pontos párhuzamát nem találtam.

Igen népszerúek voltak a középkori Magyarországon az ún. kettős kónikus palackok. Ebből az emésztőből is összesen négy palack töredéke került elő. Mivel ez az edénytípus igen vékonyfalú volt, itt is csak a fenék, a váll és a perem darabjai maradtak meg. Az egyikből egy golyvás peremtöredék, ${ }^{36}$ egy talpgyúrúdarabka és egy kis válltöredék maradt meg kissé szürkészöld árnyalatú, átlátszó, jó minőségú üvegből. Az ebből és néhány további apró darabból kiszerkeszthető, enyhén hasas alsó rész alapján egy jellegzetes, 15. századi típust képviseltek, amelyet alacsonyabb, hordó alakú alsó rész és szélesen kiugró, lekerekített, majd felfelé megtörő, homorú vállforma jellemez. A négy palack közül három színtelen, átlátszó üvegból készült velencei gyártmány volt (17. kép 9-10, 12), egy válltöredék azonban a földben sötétbarnára irizált, ez már a 15. század második felében készült hazai termék lehetett (17. kép 7). ${ }^{37}$

Korsóféleséghez tartozhatott egy belül üreges, lapított kiképzésú, viszonylag nagyobb fültöredék színtelen velencei üvegból (17. kép 3). Van egy másik, pántszerû, gyưrú alakú fültöredék is, ugyancsak színtelen velencei üvegből. Láthatóan egy igen vékony falú edényhez tapasztották, amely ennek következtében deformálódott, s mivel az edényfal a fül mentén le is tört, alakját és méretét nem lehet megállapítani (17. kép 4). A fültöredék nem egyedülálló, a visegrádi palotában ez már a harmadik ilyen jellegú darab. ${ }^{38}$ (Hasonló fülük volt a gömbös testú velencei csészéknek is, de ez a fül túl nagy ahhoz.)

\section{Poharak, csészék}

A csészék közé sorolható egy igen vékony, díszítetlen falú, színtelen velencei üvegból készült, gömbös testú edény, amelynek peremét vastag kobaltkék üvegszál díszíti (17. kép 5). Budai és konstanzi párhuzamai alapján az edényke vállán kis pántfül is lehetett, de ez sajnos nem maradt meg. Egy hasonló darab már került elő a palotában csavart bordás testtel és világoskék üvegszállal a 14. század második felére, a 15. század elejére keltezhetó rétegbő ${ }^{39}$ - de maga a típus

36 H. GYÜRKY 1991, XII/2. típus, 35-36, VIII. tábla 6.

37 Párhuzamait Óbudáról, Sarvalyról, Felsőnyékről és Vácról is ismerjük: H. GYÜRKY 1991, 25-27, 42-43, 47-48. és 36., 49. és 54. kép; H. GYÜRKY 1991a, 110-112, 7. tábla 4.

38 Mester 1997, 19., 113. és 164. kép.

39 Mester 1997, 18., 107. kép. 
évszázadokon át létezett. A darabunkhoz hasonló, sima falú példány is ismert Budáról ${ }^{40}$ és Heidelbergből.

Egy velencei minőségú, színtelen, gömbfenekú csésze töredéke is elókerült vékony oldalfallal, vastag, alul kissé visszahorpadó fenekén szépen eldolgozott fogásnyommal (17. kép 6). Hasonló, csak füstszínú darabot Budafelhévízen találtam. ${ }^{41}$

A további ivóedényeket egy nagy, ovális optikai foltokkal díszített velencei pohár darabja, ${ }^{42}$ egy sugaras bordázású, ívelt falú csészetöredék (17. kép 1-2) és egy halványzöld árnyalatú pohárka apró töredékei képviselik.

\section{Kora újkori edények}

Az emésztőbe a királyi palota 1544-ben bekövetkezett leégése és rommá válása után is bekerült elvétve egy-két törött cserépedény. Közülük egy 16. századi, vörösesbarna anyagú, ívelten szúkülő nyakú, gyưrús szájú, szalagfüles töredék érdemel figyelmet (18. kép 1), valamint néhány hódoltságkori darab. Utóbbiak egyike egy félgömbös testú, belül zöld mázas talpas tál töredéke, a másikegy tojásdad testú, kiöntőcsöves, zöld mázas korsó darabja, a harmadik pedig egy kis kiöntőcsöves korsócska teste, amelynek vállára csepp alakú végződéssel támaszkodik a fül. Ezt a korsócskát nem mázazták, külsejét vörös engobe-bal vonták be (18. kép 2).

A betöltés tetejére még a 18. század elején betelepülő svábok edényeiből is került néhány töredék, közülük a legérdekesebb egy drapp színú, talpgyürüs, tojásdad testú edény - talán kancsó - amelynek talpába utólag egy lyukat is fúrtak (18. kép 3).

\section{Összefoglalás}

A királyi palota egykori emésztője - helyzetéból adódóan - érdekes megfigyelésekre nyújtott lehetőséget különösen két korszakra: a Nagy Lajoskor elejére és a Mátyás-, illetve Jagelló-kor időszakára vonatkozóan.

Az 1350-es években használt és kidobott kerámiaanyag összetételéről nagy ívú következtetések nem vonhatók le, hiszen az emésztőt kitisztították, ezért nem tudhatjuk, hogy az alján maradt leletanyag hogyan viszonyult a kidobott és már

\footnotetext{
40 H. GYÜRKY 1987, Abb. 9. 6.

41 Kocsis 1999, 353, 6. kép 5.

42 H. GYÜRKY, 1991, 64-65, XXVIII. tábla 4.
}

meg nem ismerhető anyaghoz. A megmaradt leletek így is értékes információkkal szolgálnak. Korábban - Holl Imre budai megfigyelései és elemzései alapján - úgy véltük, hogy az ország központi régiójában a hurkatechnikával felépített, kézikorongon elsimítva készült edények gyártása a 13-14. század fordulóján lezárult. A 14. század első felében kialakuló visegrádi királyi központ ásatásaiból azonban eddig is úgy túnt, hogy a technikai váltás valamivel később, a 14. század első felében fokozatosan történt meg. Ezt erősítik meg ebben a leletanyagban a 14. század közepén földbe kerülő, még a hagyományos technikával gyártott edények is. Megfigyelhetó, hogy a régi készítési módot leginkább a fazekak, tárolóedények és a gömbtestú palackok gyártásánál őrizték meg.

Különlegesek a 14. század közepéról megmaradt tárolóedények is, hiszen formai jegyeik mutatják, hogyan vált át a régi készítési eljárás a modernebb módszerre, divatosabb formára, díszítésmódra. ${ }^{43}$

A 15. század végi, 16. század eleji használat során felhalmozódott anyag többségét az emésztó mellett múködő konyhában és kamrában használt tárgyak alkothatják. Nem szabad elfelejteni, hogy a palota ekkor már nem az ország középpontja, csupán egy időszakosan használt reprezentatív rezidencia, ezért a legszebb, legértékesebb tárgyak nem tartoztak a palota állandó felszereléséhez. Ezt figyelembe véve érdekes a konyha nagyszámú, jó minőségú fazék- és tárolóedény-készlete, amelynek egy jelentős része bécsi, tullni, passaui vagy egyéb helyról származó importáru. A hazai jó minőségú fazekak is képviselve vannak, de különös, hogy az éppen ekkoriban Budán oly elterjedtté váló vörös anyagú, engobe-os, belül mázas fazekaknak csak igen kevés töredéke fordul elő a leletek között, a lábas pedig hiányzik. Pedig a mázas belsejŭ fózőedények megjelenése valószínúleg az ételek ízében is változást hozhatott. Egyelőre megmagyarázhatatlan az emésztőbe bekerült fedők kis száma is.

$\mathrm{Az}$ asztali edények: kancsók, korsók, poharak nagy része is olcsó hazai cserépáru - a talpas poharakon jól látható az egységes méretre és formára való törekvés. Ezeket a darabokat valószínúleg a palota kiszolgáló személyzetének az ellátására készítették, az udvari elókelőségek asztalára legfeljebb az üvegpalackok és -poharak feleltek

43 BÁRDI 2014, 131-132. A diplomamunka egy a palota közelében feltárt lelóhely 14-15. századi anyagát dolgozza fel. Nem kizárt, hogy a leletek egy részének talán a királyi palota anyagához is köze lehet: az igen hasonló, 14. századi típusú edényeket tartalmazó anyag egy része akár a palotából is származhat. 
meg. Import díszkerámia csak kevés volt, s ez általánosságban igaz a királyi palota leletanyagára is. Ennek az lehet az oka, hogy az udvar előkelői inkább nemesfém poharakat, tányérokat használtak, a változatos díszkerámiákat inkább jómódú városi környezetben találhatjuk meg a drága fémedények olcsóbb utánzataiként.

Érdekesek a különleges, luxust szolgáló tárgyak töredékei is az emésztő anyagában. Ilyenek a két borvegyító edény töredékei, amelyeket lakomákon használhattak vagy a Szíriából származó orvosságos edény, valamint a Mátyás-kori palota értékes üvegcsillárjainak lámpásai. A Mátyáskori betöltésben a palota késó Zsigmond-kori kályhájának darabjai hevertek - és meglepetésként köztük egy újra felhasznált Anjou-kori csempe, amely újabb adattal gazdagította a palota kályháinak történetét.

\section{IRODALOM}

BÁRDI BOGÁTA

2014 14. századi városi leletanyag Visegrádról. Visegrád Duna-parti út 1. lelóhely kerámiaanyagának feldolBENCZE ZOLTÁN gozása. Szakdolgozat. Eötvös Loránd Tudományegyetem, Bölcsészettudományi Kar.

1992 A Hadtörténeti Intézet udvarán feltárt egyik sziklagödör kerámiája (Keramik aus einer der im Hof des Krieghistorischen Instituts freigelegten Felsengruben). Communicationes Archaeologicae Hungariae (Budapest) 209-223.

BOLDIZSÁR PÉTER

1999 Az esztergomi vár Anjou-kori kályhacsempéi (Die Ofenkachelfunde der Esztergomer Burg aus dem 14. Jh). Komárom-Esztergom Megyei Múzeumok Közleményei (Tata) 6, 281-290.

2003 Az esztergomi vár Anjou-kori kályhacsempe leletei II (Die angevinzeitliche Kachelfunde aus dem Burg von Esztergom II). Komárom-Esztergom Megyei Múzeumok Közleményei (Tata) 10, 97-125.

BOGDÁN ISTVÁN

1991 Magyarországi úr-, térfogat-, súly- és darabmértékek 1874-ig. Budapest.

ELSASS

1992 Leben in Mittelalter. 30 Jahre Mittelalterarchäologie Elsaß. Hrsg. Grewenig, M. M. Speyer.

H. GYÜRKY, KATALIN

1987 Mittelalterliche Glasfunde aus dem Vorhof des Königlichen Palastes von Buda. Acta Archaeologica Academiae Scientiarum Hungaricae (Budapest) 39, 47-68.

1991 Az üveg. Katalógus. A Budapesti Történeti Múzeum Gyújteménye. Monumenta Historica Budapestinensia 5 .

HOLL IMRE

1955 Külföldi kerámia Magyarországon (XIII-XVI. század) (Ausländische Keramikfunde des XIII-XVl. Jahrhunderts in Ungarn). Budapest Régiségei 16, 147-190.

1958 Középkori kályhacsempék Magyarországon I (Mittelalterliche Ofenkacheln in Ungarn). Budapest Régiségei 18, 211-278.

1963 Középkori cserépedények a budai várpalotából (XIII-XV. század) (Mittelalterliche Keramik aus dem Burgpalast von Buda). Budapest Régiségei 20, 335-394

1990 Ausländische Keramikfunde in Ungarn (14-15. Jh.). Acta Archaeologica Academiae Scientiarum Hungaricae (Budapest) 42, 209-267.

1992 Kőszeg vára a középkorban. Fontes Archaeologici Hungariae. Budapest.

2006 Külföldi kerámia Magyarországon III. (14-17. század) (Ausländische Keramikfunde in Ungarn III. [14-17. Jh.]). Budapest Régiségei 40, 253-294.

KOCSIS EDIT

1999 Ásatás a Tölgyfa utca 24-ben (Excavation at 24, Tölgyfa Street). Budapest Régiségei 33, 351-360.

2008 9.30.a-b. katalógustétel. In: Farbaky P.-Spekner E.-Szende K.-Végh A. (szerk.): Hunyadi Mátyás, a király. Hagyomány és megújulás a királyi udvarban 1458-1490. Kiállítási katalógus. Budapest, 369-370.

2010 Kerámia-, üveg- és fémleletek a királyi udvarból. In: Buzás G.-Orosz K. (szerk.): A visegrádi királyi palota. 381-391.

2011 Szíriai albarelló a visegrádi királyi palotából. In: Tóth E.-Vida I. (szerk.): Corolla Museologica Kovács Tibor Dedicata. Régészeti Füzetek Új Sorozat IV. szám. Budapest, 293-301.

MAJEWSKI, LAWRENCE J.

1968 Ampelkron. In: Gómez-Moreno, C. (ed.): Medieval Art from Private Collections. Special Exhibition at the Cloisters. New York. Kat. 83. 


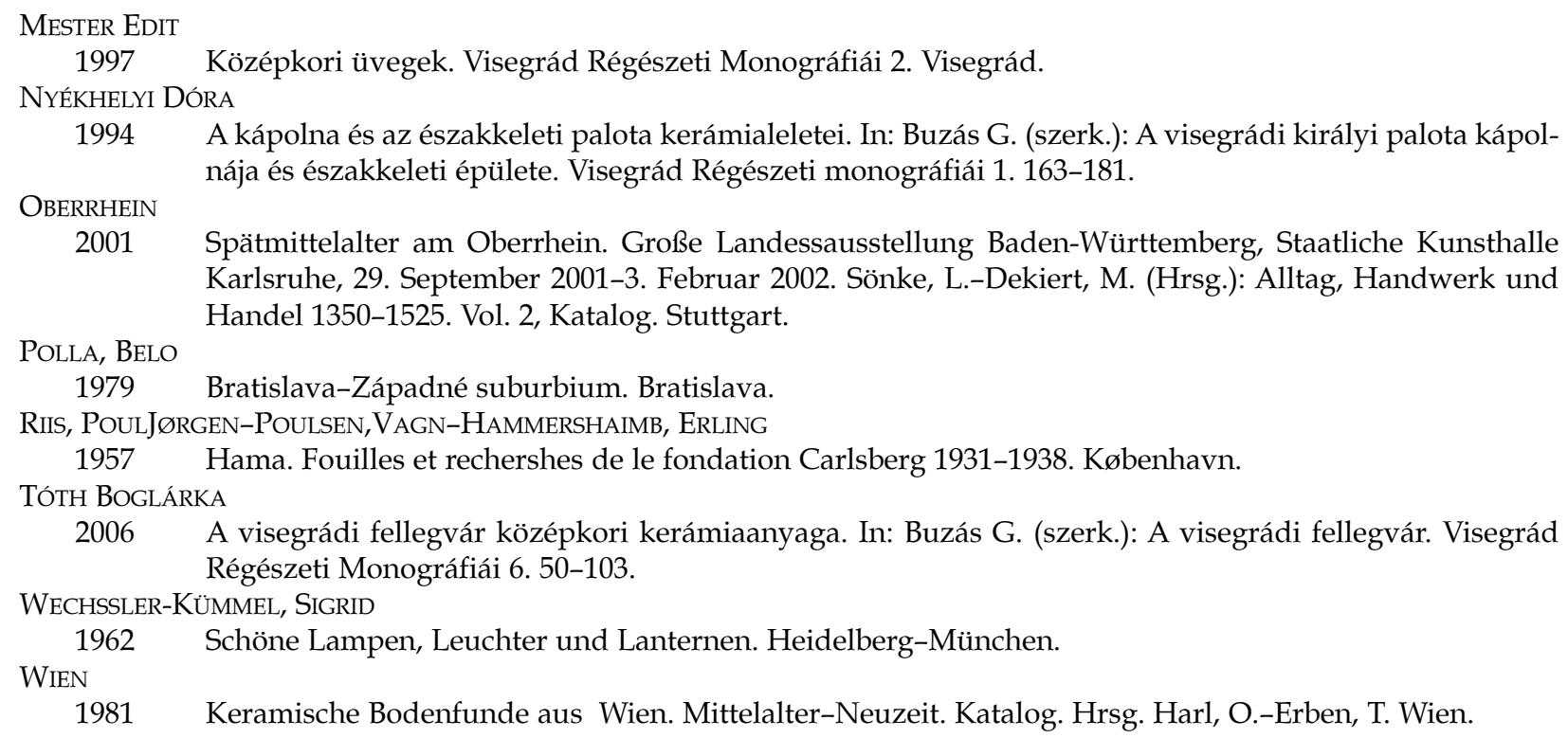

THE FINDS FROM THE MEDIEVAL CESSPIT OF THE ROYAL PALACE AT VISEGRÁD

\section{EDIT KocsIS}

The cesspit of the western wing of the royal palace at Visegrád was built in the mid-14th century and it remained in use until 1544 when the palace was destroyed. It was cleaned in the 1470s. The material recovered from its fill sheds new light on several interesting issues, especially regarding two specific periods. A part of the pottery fragments found on the cesspit's floor represents the remnants of the very first infilling beginning in the 1350s; the later infilling began after the cleaning, at the close of the 15th century, after which we found an accumulation of earlier 16th century finds.

Despite its strongly fragmented condition, the pottery used and then discarded in the 1350s provided a wealth of information. Following Imre Holl's studies on the pottery from Buda, it was earlier believed that the manufacture of vessels made using the coil technique and then smoothed on a slow wheel ended at the turn of the 13th-14th centuries in Hungary's central region. However, the excavations in the royal centre at Visegrád, emerging in the earlier 14th century, would suggest that the shift from traditional potting techniques to the production of wheel-turned wares occurred slightly later, during the earlier 14th century. The earlier manufacturing technique continued to be employed for the production of cooking pots, storage vessels and globular flasks.

In the late 15th-early 16th century, various artefacts used in the kitchen and the pantry were discarded into the cesspit. By this time, the palace was no longer the "centre of the realm", but an intermittently used representative residence, and thus the most elegant and most valuable tableware was only taken to and used at
Visegrád periodically. It is thus particularly interesting that a significant portion of the high number of good-quality cooking pots and storage vessels were imports from Vienna, Tulln, Passau and other Austrian workshops. Although good-quality Hungarian wares are also represented, curiously enough very few pieces of the engobe-covered pots with glazed interior that were quite widespread in Buda at the time came to light at Visegrád and not one single pan was found.

The greater part of the tableware - jugs, pitchers and cups - was made up of cheap, locally made pieces. The footed cups reflect a tendency for producing uniform sizes and forms. These pieces were probably acquired for the servants working in the palace, while the tableware used by the court dignitaries included glass flasks and cups. There were few imported elegant pieces, which is also true of the ceramic assemblages of the royal palace, the reason for this probably being that the court's nobles preferred cups and plates crafted from precious metal and that elegant tableware, usually imitating expensive metal vessels, was more widely used by the wealthier urban burghers.

The fragments of rare luxury items were also recovered from the cesspit. These include the fragments of two wine mixing vessels used during feasts, an albarello from Syria and the lamps of the palaces's valuable glass chandeliers from the period of Matthias's reign. The Matthiasperiod fill contained fragments of the palace's Sigismundperiod tiled stove and, surprisingly, a re-used Angevinperiod tile, which has added a new detail to the history of the palace's tiled stoves. 